\title{
3
}

\section{Princí́los de Proteção animal na Constituição de 1988}

\author{
Animal law principles in the 1988 Brazilian Constitution
}

\section{Tagore Trajano de Almeida Silva}

Tagore Trajano é Pós-doutor em Direito pela Pace Law School, New York/ USA. Doutor e Mestre em Direito Público pela Universidade Federal da Bahia (UFBA) com estágio sanduíche como Visiting Scholar na Michigan State University (MSU/USA). Professor Adjunto I da Faculdade de Direito da Universidade Federal da Bahia. E-mail: tagoretrajano@gmail.com

Recebido em:07/06/2015

Aprovado em:04/02/2016

DOI: $10.5585 / \mathrm{rdb} . \mathrm{v} 11 \mathrm{i} 5.267$

\section{Resumo}

Este artigo trata dos princípios constitucionais relacionados aos nãohumanos que podem ser extraídos do texto constitucional da Carta de 1988. Durante o período da Assembleia Nacional Constituinte a subcomissão de saúde, seguridade e meio ambiente relatou debates sobre os interesses dos animais, culminando com o artigo 225, parágrafo $1^{\circ}$, inciso VII da Constituição, no qual enunciam quatro princípios de proteção a estes seres, quais sejam, 1) dignidade animal; 2) antiespecismo; 3) não-violência; e 4) veganismo. Através de uma análise histórica e pós-humanista, conclui-se que o constituinte, no momento de elaboração da Carta Magna brasileira, teve como objetivo deixar um texto constitucional aberto que possibilitasse abranger futuros debates como o de direitos para os animais.

Palavras-chave: Assembleia Nacional Constituinte. Princípios. Direito Animal . Pós-humanismo. Direitos Fundamentais

\section{Abstract}

This paper shows the constitutional principles relating to non-humans. This article explores the effects of the article of the Brazilian Constitution that both prohibits cruelty to animals and requires governmental protection for fauna and animal species. Since the Constituent Assembly period, animals have been protected 
in the Article 225, paragraph 1, item VII. Some principles can be interpreted by Constitution, such as: 1) Animal dignity; 2) anti-speciesism; 3) non-violence; and 4) veganism. Through a historical analysis and post-humanist, it is concluded that the constituent at the time of drafting the Constitution, aimed to leave an open constitutional text that would allow cover future debates as the rights to the animals.

Keywords: Constituent Assembly - Principles - Animal Law - Post-humanism FundAMENTAL Rights.

SumÁRIo: 1. Introdução: a vez dos animais na Constituinte de 1987-1988; 2. Princípio ou regra da não crueldade? 3. Princípios constitucionais da defesa dos não-humanos; 3.1. Dignidade animal: a virada kantiana; 3.2. O antiespecismo como valor concretizador da igualdade material; 3.3. A não-violência como forma de pacificação interespécies; 3.4. Veganismo como compromisso moral com a emancipação pós-humanista; 4. Conclusão.

\section{Introdução: a vez dos animais na Constituinte de 1987-1988}

O momento de elaboração da Constituição de 1988 foi palco de diversas disputas entre grupos políticos, progressistas e conservadores, com a finalidade de construir o alicerce de uma nova sociedade. ${ }^{1}$ A nova Carta Política teve a função de definir os processos de sujeição dos fenômenos de poder, equilibrando a relação entre o poder atribuído ao Estado e, o remanescente de toda a sociedade. ${ }^{2}$

Nos anos de 1987 e 1988, o cenário era de disputas políticas, sendo diversas as pautas a serem discutidas na Assembleia Nacional Constituinte, uma delas foi em relação aos interesses dos animais não-humanos que aconteceu na subcomissão de saúde, seguridade e meio ambiente. ${ }^{3}$

1 PILATTI, Adriano. A Constituinte de 1987-1988: progressistas, conservadores, ordem econômica e regras do jogo. Rio de Janeiro: Lúmen Júris, 2008. p. 57 e ss.

2 MOREIRA NETO, Diogo de Figueiredo. Transição constitucional (pela estabilidade democrática). Revista Forense. vol. 304. p. 63-68. Rio de Janeiro: Forense, 1988. p. 66.

$3 \mathrm{Na}$ análise dos documentos da subcomissão de saúde, seguridade e do meio ambiente percebe-se que as discussões travadas em torno da temática animal, tinham um caráter antropocêntrico, buscando relacionar a proteção animal a funcionalidade de cada espécie. Valores econômicos, sociais e culturais da época foram decisivos para estabelecer o texto constitucional, uma vez que interferiam em setores ligados a alimentação, agricultura, pesquisa, dentre outros temas em pauta no momento da redemocratização brasileira. Mais sobre este tema, ver, dentre outros: DIAS, Edna Cardozo. A Defesa dos animais e as conquistas legislativas do movimento de proteção animal no Brasil. Revista Brasileira 
Desde 1984, as discussões da normatização democrática e da conquista do Estado Democrático de Direito tinham deixado de ser digressões de uma pequena parcela abastada da sociedade para tomar as ruas, em comícios, em prol de temas como a proteção animal. ${ }^{4}$

Em verdade, a formatação do catálogo dos direitos fundamentais na nova ordem constitucional foi resultado de um amplo processo de discussão sem precedentes, oportunizado com a redemocratização do país. A instalação da Assembleia Nacional Constituinte (ou Congresso-Constituinte), em $1^{\circ}$ de fevereiro de 1987, propiciou a construção de uma Carta Política com feição pluralista a englobar a temática dos animais. ${ }^{5}$

Os constituintes avançaram na consideração moral dos não-humanos, ainda durante o período de elaboração da Carta Magna brasileira, uma vez que se sensibilizaram com os clamores advindos das ruas por mudança no tratamento dos animais ${ }^{6}$.

Contemporânea de sua época, a nova Constituição buscou, em seu processo construtivo, responder a uma população cansada de regimes despóticos e de instituições instáveis ${ }^{7}$, assinalando que problemáticas como o desrespeito às

de Direito Animal/Brazilian Animal Rights Review. Ano 02. Vol. 02. jan/jun. Salvador: Evolução, 2007. p. 123-142. p. 26- ss.

4 José Afonso da Silva assevera que as "discussões públicas sobre o conteúdo de uma nova ordem constitucional preocupavam-se com o restabelecimento de três equilíbrios que se têm como objetivos de um regime constitucional democrático para o Brasil: a) o equilíbrio entre o poder estatal e os direitos fundamentais do homem; b) o equilíbrio entre os poderes governamentais - Legislativo e Executivo especialmente; c) o equilíbrio entre o poder central e os poderes regionais e locais - ou seja, equilíbrio federativo. Equilíbrios, esses, que, sendo consagrados formalmente no texto constitucional, só se manteriam eficazes mediante o estabelecimento de controles recíprocos, mas especialmente do controle popular, fundado em sistema democrático de participação no poder". SILVA, José Afonso da. O constitucionalismo brasileiro - evolução institucional. São Paulo: Malheiros, 2011. p. 82 e ss.

5 SARLET, Ingo Wolfgang. A eficácia dos Direitos Fundamentais. 8ª Ed. Porto Alegre: Livraria do advogado, 2007. p. 75-77.

6 A ideia de constitucionalização da proteção animal no Brasil coube à Liga de Prevenção de Crueldade contra o Animal - LPCA, juntamente com a União dos Defensores da terra - OIKOS e à Associação Protetora dos Animais São Francisco de Assis - APASFA. Estas associações conseguiram cerca de 11.000 assinaturas, tendo um papel decisivo na defesa do texto junto ao relator da Constituição Federal, Bernardo Cabral. O resultado desta mobilização foi à inclusão do artigo $225, \S 1^{\circ}$, VII na Constituição Federal. DIAS, Edna Cardozo. A Defesa dos animais e as conquistas legislativas do movimento de proteção animal no Brasil. Revista Brasileira de Direito Animal. Vol. 02. n. 1. jan/jun. p. 123-142. Salvador: Evolução, 2007. p. 134

MARINHO, Josaphat. Uma perspectiva da nova Constituição brasileira. 
demais formas de vida, além da humana, mereceriam importância na Constituinte Nacional, devendo ser objeto de regulamentação própria como direito fundamental. ${ }^{8}$

Paulo Affonso Leme Machado lembra que a Constituição da República Federativa do Brasil de 1988 é a primeira carta brasileira em que a expressão "meio ambiente" é mencionada, ${ }^{9}$ influência da Conferência de Estocolmo de 1972 e das Constituições de Portugal, Espanha e Grécia, as quais inspiraram o constituinte brasileiro. ${ }^{10} \mathrm{O}$ caráter evolutivo da Carta brasileira ${ }^{11}$ refletiu no seu conteúdo e em sua aplicação na medida em que constitucionalizou matérias e criou mecanismos que permitem ao intérprete efetivar seu texto ${ }^{12}$.

Nesse cenário, o caminhar, em busca de direitos para os animais foi fruto, ao mesmo tempo, de questões que estavam relacionadas aos interesses sociais

Revista Forense. Vol. 84. n. 304, p. 101 -105, out/dez. Rio de Janeiro: Forense, 1988. p. 104-105.

8 MEDEIROS, Fernanda Luiza Fontoura de. Direito dos animais. Porto Alegre: Livraria do Advogado, 2013. p. 70.

9 "Devo lembrar que na nossa Constituição atual, a palavra meio ambiente e ecologia não existem, não foi falado nunca. Existe apenas um artigo, que é o art. 172 da Emenda Constitucional n ${ }^{\circ} 1$ de 1969, que fala de erosão e de poluição. De tal modo que a nossa Constituição está muito atrasada em relação às Constituições modernas, surgidas, principalmente, depois da Conferência de Estocolmo. Nessas novas Constituições existem capítulos muito bem fundamentados, como o de meio ambiente, que dão subsídio à legislação que daí saía". Corrobora a nota anterior, debate ainda na Assembleia Constituinte sobre o meio ambiente como norma constitucional: Discurso de Ângelo Barbosa Machado - representante da SBPC - Sociedade brasileira para o progresso da ciência. p. 177. Disponível em: http://www.senado. gov.br/publicacoes/anais/constituinte/7b\%20-\%20SUBCOMISS $\%$ C3\%83O $\% 20$ DE\%20SA\%C3\%9ADE,\%20SEGURIDADE\%20E\%20MEIO\%20AMBIENTE. pdf. Acesso em: 01 jun. 2012.

10 Para Paulo Affonso Machado foi "a Emenda Constitucional 1/1969 a utilizar pela primeira vez em um texto constitucional brasileiro - a expressão 'ecológico', dizendo seu art. 172: 'A lei regulará, mediante prévio levantamento ecológico, o aproveitamento agrícola de terra sujeitas a intempéries e calamidades'. Nas Constituições, espanhola, portuguesa e grega, esses aspectos são tratadas seriamente. E, coincidentemente, são países que saíram de um regime ditatorial, e que na Nova República de cada um levaram a sério o problema meio do ambiente, de tal modo a inseri-lo nas suas Constituições". MACHADO, Paulo Affonso Leme, Direito Ambiental Brasileiro. 13a ed. São Paulo: Malheiros, 2005. p. 115.

11 CANOTILHO, José Joaquim. Direito Constitucional e Teoria da Constituição. $7^{\circ}$ ed. Coimbra: Almedina, 2004. p. 81.

12 TAVARES, Ana Lúcia de Lyra. A Constituição Brasileira de 1988: subsídios para os comparatistas. Revista de Informação Legislativa. Brasília. Ano 28. nº 109. jan/mar. p. 71-108. 1991. p. 86. 
e econômicos do homem, sejam aqueles referentes à pesquisa e experimentação, sejam os atinentes a agricultura e a alimentação; como também, do resultado de um dever indireto relacionado à proteção dos animais. ${ }^{13}$

Os interesses dos não-humanos emergem, nos primeiros momentos, em fórmula estritamente antropocêntrica, derivada dos conceitos de vida e dignidade humanas, sendo, somente mais tarde, percebidos no texto constitucional sob feições

13 Em seu discurso, a Dr. ${ }^{a}$ Fernanda Colagrossi, representantes da Câmara Técnica de acompanhamento da Constituinte do Conselho Nacional do Meio Ambiente de 1988, sintetizou os principais temas da época referentes à temática dos não-humanos, relatando questões referentes ao abate de animais, vivissecção e a farra do boi, transcritos ao lado: "No abate dos equídeos, por exemplo - e eu trouxe aqui uma carta de que existem três abatedouros: um em Minas Gerais, outro no Rio de Janeiro e um outro na Bahia - eles estão usando o seguinte método: eles colocam o cavalo num boxe, num pequeno compartimento. $\mathrm{O}$ cavalo não pode se deitar, não pode se sentar, e uma serra circular, a trinta centímetros do chão, é utilizada para cortar as quatro patas do cavalo. O cavalo, sentindo uma dor incrível, não pode se deitar e cai em cima dos cotos, em cima do corte, e começa a tremer e a suar enormemente, e isto faz com que o seu couro possa ser utilizado, depois, para sapatos e bolsas, para utensílios finos. [...] Estou citando apenas alguns fatos para mostrar aos senhores a importância de regulamentar, através da Constituição, o uso em relação aos animais não apenas da nossa fauna, mas em relação aos animais que nós usamos. [...] Quanto à vivissecção, a situação é a seguinte: existe uma lei, Lei no 6.638 , de 8 de maio de 1979, publicada já no Diário Oficial, que proíbe as experiências de vivissecção nas escolas de $1^{\circ}$ e $2^{\circ}$ graus e locais frequentados por menores. Essa lei dava ao Poder Executivo o prazo de 90 dias para regulamentação. Justamente nos biotérios, que são os lugares que podem ser feitas essas experiências, que tivessem um médico veterinário, assistência e fiscalização. Queria dizer aos senhores que no litoral de Santa Catarina existe uma cultura, de origem açoreana, que se chama farra do boi - os senhores devem ter lido nos jornais - que é feita na Semana Santa. [...] Esse boi é dado à população pelos políticos locais, normalmente, sobretudo em época de eleições, e esse boi tem os olhos furados, tocam fogo no rabo, enfiam ferro nas suas cavidades, são cortados lentamente, e quando eles morrem antes do tempo, porque eles devem morrer apenas no Sábado de Aleluia, outros bois são trazidos. [...] Eu só queria pedir, aqui nesta sala, de tanta importância para a Constituição, de tanta importância para as leis que vão nos reger: piedade! Não só aos animais, como também à nossa alimentação. E que seja feita na Constituição alguma coisa muito firme e muito séria em relação à morte dos animais que nos alimentam, dos animais que nos servem e que nós utilizamos. Disponível em: http://www.senado. gov.br/publicacoes/anais/constituinte/7b $\% 20-\% 20$ SUBCOMISS $\%$ C 3\%83O $\% 20$ DE\%20SA\%C3\%9ADE,\%20SEGURIDADE\%20E\%20MEIO\%20AMBIENTE. pdf. Acesso em: 01 de junho de 2012. 


\section{biocêntricas. ${ }^{14}$}

A inserção do art. 225, parágrafo $1^{\circ}$, inciso VII na Constituição de 1988 foi projeto de intenso debate e discussão em todo o país, decorrência de uma verdadeira virada kantiana, ocorrida ainda durante a Assembleia Nacional, em prol dos interesses não-humanos. ${ }^{15}$ Pode-se dizer que o constituinte brasileiro deixou as portas abertas para a pós-humanização de sua Carta $^{16}$ ao atualizá-la com ideais que vão além da categorização humana, reconhecendo um valor em si inerente a todos os animais não-humanos, permitindo, através de seu texto, uma interpretação que contemple a dignidade animal. ${ }^{17}$

É, portanto, da Constituição que derivam os mandamentos de otimização que regem o Direito Animal, sendo quatro os princípios que serão abordados ao decorrer deste trabalho: 1) dignidade animal; 2) antiespecismo; 3 ) não-violência; e 4) veganismo. Contudo, antes de analisar cada um deles no presente artigo, é necessário

14 BENJAMIN, Antonio Herman. Constitucionalização do ambiente e ecologização da constituição brasileira. In: CANOTILHO, J.J. Gomes; LEITE, José Rubens Morato (org.). Direito Constitucional. Ambiental Brasileiro. São Paulo: Saraiva, 2007. p. 64.

15 Cf. BARROSO, Luís Roberto. Gestação de fetos anencefálicos e pesquisas com células-tronco: dois temas acerca da vida e da dignidade da pessoa humana. Revista de Direito Administrativo. Rio de Janeiro. Vol. 241, p. 93-120, 2005.

16 Em entrevista concedida ao autor, Fábio Feldmann reconhece que o objetivo do constituinte foi deixar um texto constitucional aberto que possibilitasse abranger futuros debates como o de direitos para os animais. Para Feldmann a norma constitucional do art. 225, $\S 1^{\circ}$, VII foi resultado da síntese dos debates sobre a crueldade que acontecia: 1) na farra do boi em Santa Catarina; 2) com os equídeos em São Paulo; e 3) com as baleias. Entrevista sobre as razões do art. 225, §1 ${ }^{\circ}$, VII e a Assembleia Constituinte de 1987/1988 em 16 de Julho de 2013. Sobre o encontro, ver: FELDMANN, Fábio. Os tribunais e o direito à vida do pato mergulhão. In: Brasil Econômico. Disponível em: http://brasileconomico.ig.com.br/noticias/os-tribunais-e-odireito-a-vida-do-pato-mergulhao_134442.html. Acessado em: 01 de Agosto de 2013.

17 Este intenso debate ocorrido na constituinte brasileira possibilitou a elaboração de dispositivo constitucional a vedar qualquer forma de crueldade com os animais, proposto pelo deputado constituinte Fábio Feldmann: "Queria dizer que, depois da farra do boi, e conhecendo também essa situação, estou apresentando um dispositivo constitucional, uma proposta de dispositivo constitucional, que veda a crueldade contra os animais". Discurso do deputado Fábio Feldmann - vice-presidente da subcomissão de saúde, seguridade e meio ambiente da Constituinte de 1988. p. 176. Disponível em: http://www.senado. gov.br/publicacoes/anais/constituinte/7b\%20-\%20SUBCOMISS $\%$ C 3\%83O $\% 20$

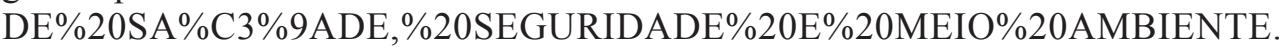
pdf. Acesso em: 01 de junho de 2012. 
compreender a norma constitucional que trata dos animais.

\section{Princípio ou regra da não crueldade?}

A distinção entre princípios e regras é ponto de partida para o entendimento do Direito Animal. O constitucionalismo atual tem estabelecido três premissas fundamentais para a compreensão dos sistemas jurídicos ocidentais, situando do ponto de vista metodológico-formal que existe: 1) uma normatividade da Constituição, reconhecendo que seus dispositivos são normas jurídicas dotadas ${ }^{18}$, como as demais, de imperatividade ${ }^{19}$; 2) uma supremacia da Constituição sobre o restante da ordem jurídica; e, 3) uma mudança de perspectiva jurídica, ao instituir a centralidade do documento constitucional, pontuando que os demais ramos do Direito devem ser compreendidos e interpretados a partir dos dizeres constitucionais. ${ }^{20}$

À vista disto, a análise dos princípios constitucionais em favor dos nãohumanos deve abranger uma nova postura por parte dos poderes públicos, dentre eles o Judiciário, no sentido de promover a efetiva reforma social e a consolidação da democracia ${ }^{21}$, visando à defesa e à concretização dos direitos fundamentais de todos. $^{22}$

Esse projeto jurídico-político comum a englobar a dimensão social e ecológica inserida na Lei Fundamental, ${ }^{23}$ atribui um tratamento especial aos animais não-humanos e ao ambiente como um todo ${ }^{24}$, possibilitando ao seu aplicador à

18 Cf. HESSE, Konrad. A Força Normativa da Constituição. Porto Alegre: Sergio Antônio Fabris, 1991.

19 BOBBIO, Norberto. Teoria do ordenamento jurídico. $7^{\circ}$. ed. Trad. Maria Celeste Cordeiro Leite dos Santos. Brasília: UNB, 1996. p. 21 e ss.

20 Premissaspropostas porBARCELLOS,AnaPaulade.Neoconstitucionalismo, Direitos Fundamentais e Controle das Políticas Públicas. Revista de Direito Administrativo. Vol. 240, p. 83-103, 2005. p. 83 e ss.

21 Ver sobre a relação entre democracia e direito animal, dentre outros: RABENHORST, Eduardo Ramalho. Dignidade Humana e Moralidade Democrática. Brasília: Brasília Jurídica, 2001. p. 9.

22 MARIANO, Cynara Monteiro \& LIMA, Martônio Mont'Alverne Barreto. Os Paradigmas Tradicionais de Justiça Constitucional e a Terceira Via do Sistema Francês. Novos Estudos Jurídicos (Online). Vol. 17. n. 02. p. 173-184. Maio/Agosto, 2012. p. 175.

23 FENSTERSEIFER, Tiago. Direitos Fundamentais e Proteção do Ambiente: a dimensão ecológica da dignidade humana no marco jurídico-constitucional do Estado Socioambiental de Direito. Porto Alegre: Livraria do Advogado, 2008. p. 9495.

24 ANTUNES, Paulo de Bessa. Direito Ambiental. 14 ed. São Paulo: Atlas, 
adaptação de suas normas a novas situações, ainda que não antecipadas pelo legislador, mas compreendidas na ordem de valores que o inspirou e nas possibilidades e limites oferecidos pelo texto normativo. ${ }^{25}$

Humberto Ávila ensina que "normas não são textos nem o conjunto deles, mas os sentidos construídos a partir da interpretação sistemática de textos normativos" ${ }^{26}$ Os dispositivos constitucionais são objetos da interpretação, tendo na norma o seu resultado. ${ }^{27}$ Esta construção de sentido feita pelo intérprete é fundamental para a distinção da qualificação das normas como princípios ou como regras. ${ }^{28}$

Princípios e regras são normas jurídicas, porque ambos dizem o que deve ser. ${ }^{29}$ Para a compreensão do direito fundamental prescrito na Carta Constitucional em defesa dos animais não-humanos, é necessário estabelecer a diferença entre regras e princípios, entendendo que vários são os critérios para estabelecer esta distinção. ${ }^{30}$

Em geral, regras prescrevem atos relativamente específicos, ao revés, princípios são normas com grau de generalidade relativamente mais alto. ${ }^{31} \mathrm{~A}$

2012. p. 21.

25 BARROSO, Luís Roberto. Interpretação e aplicação da Constituição: fundamentos de uma dogmática constitucional transformadora. 6ạ ed. São Paulo: Saraiva, 2004. p. 94 e ss. 26 ÁVILA, Humberto. Teoria dos princípios - da definição à aplicação dos princípios jurídicos. $2^{\mathrm{a}}$ ed. São Paulo: Malheiros, 2003. p. 22.

27 GRAU, Eros Roberto. Ensaio e discurso sobre interpretação/aplicação do direito. São Paulo: Malheiros, 2002. p. 151.

28 Diversos foram os autores a escrever sobre a diferença entre princípios e regras. Adota-se a classificação feita por Ronald Dworkin, posteriormente aperfeiçoada por Robert Alexy. Sobre essa questão ver: Karl Larenz, ClausWilhelm Canaris, Josef Esser, Vezio Crisafulli, dentre outros. A explicação de cada um dos autores dentro de uma perspectiva pós-humanista em defesa dos animais não-humanos pode ser encontrada em: MEDEIROS, Fernanda Luiza Fontoura de. Direito dos animais. Porto Alegre: Livraria do Advogado, 2013.

29 ALEXY, Robert. Teoria dos Direitos Fundamentais. Trad. Virgílio Afonso da Silva. São Paulo: Malheiros, 2008. p. 87.

30 BRITO, Edvaldo. Limites da revisão constitucional. Porto Alegre: Sérgio Antônio Fabris Editor, 1993. p. 65.

31 Joseph Raz exemplifica dizendo que fumar é um ato muito específico que é realizado por um tubo de fumar, um cigarro ou um charuto, mas não por muitos outros atos genéricos. Assalto, assassinato, estupro, e excesso de velocidade são igualmente atos relativamente específicos, por isto prescritos por regras. Promover a felicidade humana, o respeito humano, sua dignidade, aumento da produtividade e de se comportar de forma injusta ou excessiva são atos muito inespecíficos, objeto dos princípios. RAZ, Joseph. Legal principles and the limits of law. Yale Law Journal. Vol. 81. p. 823-854. 1972. p. 825 e ss. 
natureza entre os dois conceitos é de natureza lógica. Os dois padrões apontam para decisões particulares acerca da obrigação jurídica em circunstâncias específicas, mas distinguem-se quanto à natureza da orientação que oferecem..$^{32}$ As regras são aplicáveis à maneira tudo-ou-nada. ${ }^{33}$ Dados os fatos que uma regra estipula, então ou a regra é válida, e neste caso a resposta que ela fornece deve ser aceita, ou não é válida, e neste caso em nada contribui a decisão. ${ }^{34}$

Os princípios possuem uma dimensão de peso ou importância ${ }^{35}$. Os princípios não apresentam uma pretensão de exclusividade ${ }^{36}$, mas sim orientam os fundamentos através de um balanceamento de valores e interesses encontrados em outros princípios, sem que nenhum deles perca sua validade ${ }^{37}$. Princípios são mandamentos de otimização e exigem sua realização na maior medida possível, mas sempre de acordo com as possibilidades fáticas e jurídicas do caso concreto. ${ }^{38}$

Consoante esta diferenciação, não resta caminho a ser adotado senão o de afirmar que o legislador constituinte estabeleceu uma regra expressa por uma proibição, vedando a crueldade contra os animais ${ }^{39}$. O constituinte, ao dirigir um dever de proteção dos animais não-humanos, veda categoricamente a submissão dos animais à crueldade, não deixando espaço para ponderações, pois, como parece, não se pode ser mais ou menos cruel, sendo necessária uma realização por completo

HUGHES, Graham. Rules, Policy and Decision Making, Yale Law Journal. Vol.. 77. p. 411-439. n. 03. January, 1968. p. 419 e ss.

33 DWORKIN, Ronald. Taking Rights Seriously. Cambridge, MA: Harvard University Press, 1977. p. 26. Em português: Levando os direitos a sério. Trad. Nelson Boeira. 2 ed. São Paulo: Martins Fontes, 2007. p. 39.

34 CHRISTIE, George C. The Model of Principles. Duke Law Journal. Vol. 17. p. 649-669. 1968. p. 668.

35 DWORKIN, Ronald. The Model of Rules. University of Chicago Law Review. Vol. 34. p. 14- 46. 1967. p. 27.

36 LARENZ, Karl. Metodologia da ciência do direito. Trad. José Lamego. Lisboa: Calouste Gulbenkian, 1997. p. 236.

37 BASTOS, Celso Ribeiro. MEYER-PFLUG, Samantha. A interpretação como fator de desenvolvimento e atualização das normas constitucionais. In SILVA, Virgílio Afonso (Coord.). Interpretação constitucional. São Paulo: Malheiros, 2005. p. 150.

38 SILVA, Virgílio Afonso da. A constitucionalização do direito: os direitos fundamentais nas relações entre particulares. São Paulo: Malheiros, 2005, p. 34.

39 SANTANA, Luciano Rocha \& SANTOS, Clarissa Pereira Gunça dos. O crime de maus-tratos aos animais: uma abordagem sobre a interpretação e a prova de materialidade e autoria (artigo 32). In MARCHESAN, Ana Maria Moreira \& STEIGLEDER, Annelise Monteiro. (org.). Crimes Ambientais Comentários à Lei 9.605/98. Porto Alegre: Livraria do Advogado, 2013. p. 152. 
deste mandamento. ${ }^{40}$

Pode-se extrair do texto constitucional um imperativo categórico em defesa dos não-humanos ${ }^{41}$, um sinal invisível dizendo: "Entrada proibida", a impedir que: 1) os homens não são livres para tirar vidas ou ferir a integridade dos demais seres como bem entenderem; e 2) o ser humano não é livre para interferir nas escolhas dos demais seres da Terra, esculpindo narcisicamente os moldes da vida no planeta. ${ }^{42}$

Com efeito, não se observa grau de generalidade ou abstração no comando constitucional, podendo a regra ter aplicação imediata e direta nas situações em que haja indício de maus tratos em desfavor dos animais ${ }^{43}$. Esse foi o entender do próprio constituinte ao tratar do caso de maus-tratos acontecido na farra do boi ${ }^{44}$, como visto nos fundamentos do art. 225, $\S 1^{\circ}$, VII ainda durante a Assembleia Constituinte, juízo compartilhado posteriormente pelo Supremo Tribunal Federal na decisão do Recurso Extraordinário $\mathrm{n}^{\mathrm{o}} 153.531-8 / \mathrm{SC} .{ }^{45}$

A vedação constitucional de crueldade contra os animais deixa um claro sinal de reconhecimento da existência de um dever no tratamento e nas práticas dos

40 ALEXY, Robert. Teoria dos Direitos Fundamentais. Trad. Virgílio Afonso da Silva. São Paulo: Malheiros, 2008. p. 92.

41 Em relação à vida como um todo, ver: CANOTILHO, José Joaquim Gomes. Democracia sustentada e Estado Constitucional Ecológico. RevCEDOUA. Vol. 02. Ano. 04. p. 09-16. 2001.p. 13.

REGAN, Tom. Jaulas Vazias. Porto Alegre: Lugano, 2006. p. 47.

43 Cf. KRELL, Andreas J. Constituição e direitos dos animais. Palestra proferida no $3^{\circ}$ Congresso Mundial de Bioética e Direitos dos Animais. Realizada em 25 de Agosto de 2012. Recife: Universidade Federal de Pernambuco, 2012.

44 Sobre a ponderação de interesses em favor dos não-humanos e a construção de uma teoria brasileira que trate sobre os direitos dos animais, ver: SILVA, Tagore Trajano de Almeida. Brazilian Animal Law Overview: Balancing Human and NonHuman Interests. Journal of Animal Law. Vol. 06. p. 81-104. 2010.

45 Concluído o julgamento do recurso extraordinário interposto contra acórdão do Tribunal de Justiça de Santa Catarina que julgou improcedente ação civil pública ajuizada por entidades de proteção aos animais contra omissão do Estado em reprimir a "Farra do Boi". A Segunda Turma, por maioria, entendeu que a referida manifestação popular, ao "submeter os animais a crueldade", ofende o inciso VII do $\S 1^{\circ}$ do art. 225 da CF. Vencido o Min. Maurício Corrêa que entendia, de um lado, que o Estado deve garantir a todos o pleno exercício dos direitos culturais, bem como proteger as manifestações das culturas populares - tal como dispõe o art. 215 caput e respectivo $\S 1^{\circ}$ da CF -, coibindo eventuais excessos; e de outro, que se tratava de questão de fato e não de direito, o que é incompatível com o extraordinário. RE 153.531-SC, Rel. Min. Francisco Rezek, rel. p/ o acórdão Min. Marco Aurélio (art. 38, IV, b do RISTF) 10.6.97. 
seres humanos em face dos não-humanos ${ }^{46}$. A constitucionalização dos direitos dos animais pós-humaniza o processo interpretativo, apresentando um novo caminho, ao entender que todos (= todos os seres vivos humanos e não-humanos da Terra) têm direito ao meio ambiente ecologicamente equilibrado, devendo defendê-lo e preservá-lo para as presentes e futuras gerações (= presentes e futuras gerações de vida no planeta).$^{47}$

Este fluxo hermenêutico introduz novos atores, impõe novos conceitos e exige um reposicionamento de antigas teorias ${ }^{48}$, dentre elas, a que afirma que a norma constitucional de proteção aos não-humanos figura auto-executável ${ }^{49}$ (selfexecuting $)^{50}$, ou, conforme atual classificação ${ }^{51}$, norma constitucional de eficácia plena e aplicabilidade imediata. ${ }^{52}$

46 SARLET, Ingo Wolfgang, FENSTERSEIFER, Tiago. Direito Constitucional Ambiental: Estudos sobre a Constituição, os Direitos Fundamentais e a Proteção do Ambiente. São Paulo; Editora Revista dos Tribunais, 2011. p. 166.

47 Sobre o tema: SILVA, Tagore Trajano de Almeida. Direito Animal e ensino jurídico: formação e autonomia de um saber pós-humanista. 1. ed. Salvador: Evolução, 2014. p. 93 e ss.

48 LIMA, Martônio Mont'Alverne Barreto. Política versus Direito: Real Desafio da Jurisdição Constitucional?. In: Lorena Freitas; Enoque Feitosa. (Org.). Marxismo, Realismo e Direitos Humanos. João Pessoa - PB: Editora da Universidade Federal da Paraíba, 2012, v. 1, p. 52-66. p. 54.

49 Cf. BARBOSA, Rui. Comentários à Constituição Federal brasileira. São Paulo: Saraiva, 1933. p. 448 e ss.

50 Cf. COOLEY, Thomas M. A Treatise on the Constitutional Limitations Which Rest upon the Legislative Power of the States of the American Union. $5^{\circ}$ ed. Boston: Little, Brown \& Co., 1883. Sobre os limites da interpretação constitucional no pensamento de Cooley, ver: CARRINGTON, Paul D. The Constitutional Law Scholarship of Thomas McIntyre Cooley. American Journal of Legal History. Vol. 41. p. 368-399. 1997. p. 372.

51 SILVA, José Afonso. Aplicabilidade das Normas Constitucionais. $7^{\mathrm{a}}$ ed. São Paulo: Malheiros, 2008. p. 81 e ss.

52 Nessa esteira, Wilson Steinmetz afirmar que: “A CF, no $\S 1^{\circ}$ do art. $5^{\circ}$, determina que 'as normas definidoras dos direitos e garantias fundamentais têm aplicação imediata'. Na literatura constitucional, diz-se que se trata do princípio da aplicabilidade imediata dos direitos fundamentais. A partir desse enunciado constitucional, fundamenta-se a vinculação imediata ou direta dos poderes públicos - Legislativo, Executivo e Judiciário - aos direitos fundamentais e a eficácia imediata desses direitos, no sentido de um mandamento de máxima eficácia possível". STEINMETZ, Wilson. A vinculação dos particulares a direitos fundamentais. São Paulo: Malheiros, 2004. p. 121-122. 
A estrutura normativa de defesa dos animais ganha feições de um direitodever $^{53}$, avançando para a existência de um dever fundamental ecológico que encontra seu suporte constitucional na vedação da crueldade.$^{54}$ Há a formação de uma verdadeira obrigação de defesa e assistência aos animais, tendo o Estado a função de proteger ativamente o direito fundamental dos animais contra as ameaças de violação. ${ }^{55}$

$\mathrm{Na}$ defesa dos não-humanos, esta proteção pode acontecer de duas formas, através: 1) da abstenção de comportamento lesivo próprio, ou seja, refere-se à obrigação de não intervenção nas esferas individuais protegidas, e 2) da ação do Estado no intuito de preservar ativamente os direitos fundamentais em face das possíveis inobservâncias de particulares. ${ }^{56}$

Cabe ao estado forçar o respeito aos direitos fundamentais, inclusive através de suas instituições ${ }^{57}$, impondo a omissão de condutas violadoras provenientes de particulares, bem como estimulando condutas em prol da defesa dos animais, até mesmo preventivamente por meio do Poder Legislativo. ${ }^{58}$ Dito de outro modo, há uma dupla dimensão da eficácia das normas constitucionais dirigidas aos animais não-humanos, uma a garantir direitos subjetivos protegidos pelo Estado e outra a preservar eventuais violações por parte dos particulares. ${ }^{59}$

53 De acordo com Saulo Casali ao asseverar que a Constituição brasileira desenha seu sistema de direitos fundamentais através de um complexo de direitos e deveres. Ver: BAHIA, Saulo José Casali. Human Rights from a Latin American Perspective. Forum on Public Policy. Vol. 09. p. 1-29. Summer, 2009. p. 03.

54 CANOTILHO, José Joaquim Gomes. Democracia sustentada e Estado Constitucional Ecológico. RevCEDOUA. Vol. 02. Ano. 04. p. 09-16. 2001. p. 13.

55 DIMOULIS, Dimitri; MARTINS, Leonardo. Teoria geral dos direitos fundamentais. São Paulo: Revista dos. Tribunais, 2008. p. 121.

56 Para a obtenção de um panorama internacional sobre o tema, ver, dentre outros: SARMENTO, Daniel. Direitos fundamentais e relações privadas. $2^{\mathrm{a}}$. ed. Rio de Janeiro: Lumen Juris, 2006. p. 144.

57 Sobre este tema ver: SANTANA, Luciano Rocha. Ministério Público e Éticas da Natureza. In OLIVEIRA, Thiago Pires; MINAHIM, Maria Auxiliadora; FREITAS, Tiago Batista. (Org.). Meio ambiente, direito e biotecnologia: estudos em homenagem ao Prof. Dr. Paulo Affonso Leme Machado. Curitiba: Juruá, 2010. p. 553.

58 DIMOULIS, Dimitri; MARTINS, Leonardo. Teoria geral dos direitos fundamentais. São Paulo: Revista dos. Tribunais, 2008. p. 121.

59 SARLET, Ingo Wolfgang, FENSTERSEIFER, Tiago. Algumas notas sobre a dimensão ecológica da dignidade da pessoa humana e sobre a dignidade da vida em geral. Revista Brasileira de Direito Animal/Brazilian Animal Rights Review. Salvador. Vol. 03. ano 02. p. 69-94. jul/dez. 2007. p. 87. 
Apesar de ser este o posicionamento da maior parcela da doutrina, em relação à eficácia da regra da não crueldade, há compreensão no sentido contrário, asseverando se tratar de norma de eficácia contível ${ }^{60}$, porque, embora dotada de aplicabilidade direta e imediata, pode sofrer limitação quanto a sua eficácia pela ação do legislador ordinário. Um exemplo pode ser encontrado na Lei $n^{0} 11.794 / 2008$, Lei Arouca, ao regulamentar o inciso VII do $\S 1^{\circ}$ do artigo 225 da Constituição Federal, estabelecendo procedimentos para o uso científico de animais. ${ }^{61}$

De fato, a imagem da Constituição como um sistema normativo aberto de princípios, regras e procedimentos ${ }^{62}$ a constituir um emaranhado de disciplinas a nortear os valores curriculares do curso de direito, ganha feições inovadoras, no momento que se pós-humaniza. Expande-se com feições multiculturais ${ }^{63}$ dentro de uma sociedade multicêntrica ${ }^{64}$, de risco $^{65}$ que teme um futuro incerto que está por vir, mas almeja garantir uma sadia qualidade de vida a todos os seres da Terra.

Este novo Constitucionalismo: verde, animal, ecológico, socioambiental e preferencialmente pós-humanizado, abrange o novo conceito de Constituição

60 DINIZ, Maria Helena. Normas constitucionais e seus efeitos. Saraiva: São Paulo, 1989. p. 97.

61 Contrariamente: SILVA, Tagore Trajano de Almeida. A Lei Arouca: ainda continuamos a realizar pesquisas com animais. Pensata Animal. Vol. 17, p. 01-06, 2008.

62 OLIVEIRA, Fábio Corrêa Souza de. Por uma Teoria dos Princípios. O Princípio Constitucional da Razoabilidade. Rio de Janeiro: Lumen Juris, 2003. p. 32.

63 Cf. SANTOS, Boaventura de Sousa. Por uma concepção multicultural de direitos humanos. Revista Crítica de Ciências Socias. nº 48. Junho, 1997.

64 Ver, dentre outros, BAUMAN, Zygmunt. Globalização: as consequências humanas. Rio de Janeiro: Jorge Zahar, 1999 e, em especial, Modernidade líquida. Rio de Janeiro: Jorge Zahar, 2001. "A educação e a aprendizagem no ambiente líquidomoderno, para ser úteis, devem ser contínuas e durar toda a vida. Nenhum outro tipo de educação e/ou aprendizagem é concebível; a 'formação' do próprio eu, ou da personalidade, é impensável de qualquer outro modo que não seja aquele contínuo e perpetuamente incompleto". Ver, dentre outros educadores: PORCHEDDU, Alba. Zygmunt Bauman: entrevista sobre a educação. Desafios pedagógicos e modernidade líquida. Cad. Pesquisa., São Paulo, v. 39, n. 137, Aug. 2009. Available from $<$ http:// www.scielo.br/scielo.php?script=sci_arttext\&pid=S0100-15742009000200016\&ln $\mathrm{g}=\mathrm{en} \& \mathrm{nrm}=\mathrm{iso}>$. Access on 03 June 2012. http://dx.doi.org/10.1590/S010015742009000200016.

65 Cf. BECK, Ulrich. Risikogesellschaft - Auf dem Weg in eine andere Moderne (1986). Primeiramente trabalhado no Brasil por: LEITE, José Rubens Morato, AYALA, Patrick de Araújo. Direito ambiental na sociedade de risco. $2^{\mathrm{a}}$. ed. Rio de Janeiro: Forense Universitária, 2004. 
Ecológica $^{66}$ difundida já nos países europeus (Alemanha e Suíça) ${ }^{67}$ e ganhando forma nos países sul-americanos como a Venezuela, Bolívia e Equador. ${ }^{68}$

Este espectro de valores, construídos em torno da Carta Política brasileira, é terreno fértil para o surgimento dos princípios constitucionais a reger o Direito Animal, avançando da regra da não crueldade e de sua relação com a dignidade da pessoa humana para a concepção da dignidade animal.

\section{Princípios constitucionais da defesa dos não-humanos}

\subsection{Dignidade animal: a virada kantiana}

Como se pôde depreender dos tópicos anteriores, a Constituição Brasileira distinguiu-se das demais por sinalizar o reconhecimento, por parte do constituinte, do valor inerente a outras formas de vida não-humanas ${ }^{69}$, protegendo-as, inclusive, contra a ação do homem, sinalizando refutar uma visão meramente instrumental da vida animal. ${ }^{70}$

Esta virada kantiana, fruto da constituinte brasileira, ampliou o conceito de Immanuel Kant ${ }^{71}$ na tentativa de conceber uma dignidade da vida para além do

66 Obra referência sobre o tema, em alemão: STEINBERG, Rudolf. Der ökologische Verfassungsstaat. Frankfurt a.M.: Suhrkamp, 1998. Ver do autor, dentre outros, STEINBERG, Rudolf, Judicial Review of Environmentally-Related Administrative Decision-Making, 11 Tel Aviv U. Stud. L. 61, 64 (1992) e Enforcing Environmental Laws: The Role of Public Law n Environmental Protection - a European Perspective 14 Tel Aviv U. Stud. L. 43 1998. O autor aponta para uma transformação histórica do conceito de Constituição, um último estágio na evolução científica, constatando a possibilidade de perda da sua força normativa diante da crise ambiental.

67 KELCH, Thomas G. Globalization and Animal Law: Comparative Law, International Law and International Trade. Great Britain: Kluwer Law International, 2011. p. 271.

68 LOURENCO, Daniel Braga. \& OLIVEIRA, Fábio Corrêa Souza de. Sustentabilidade, Economia Verde, Direito dos Animais e Ecologia Profunda: algumas considerações. Revista Brasileira de Direito Animal. Vol. 10. Ano. 07. p. 191-233, 2012. p. 200.

69 Cf. SILVA, Tagore Trajano de Almeida. Animais em juizo. Salvador: Evolução, 2012.

70 SARLET, Ingo Wolfgang, FENSTERSEIFER, Tiago. Algumas notas sobre a dimensão ecológica da dignidade da pessoa humana e sobre a dignidade da vida em geral. Revista Brasileira de Direito Animal/Brazilian Animal Rights Review. Salvador. Vol. 03. ano 02. p. 69-94. jul/dez. 2007. p. 87.

71 Cf. KANT, Immanuel. Fundamentação da metafísica dos costumes. Trad. 
ser humano que conceda aos demais animais um valor intrínseco a ser respeitado e reconhecido pelo direito. ${ }^{72} \mathrm{~A}$ dignidade, desta forma, não seria atributo exclusivo da pessoa humana, mas também de todas as formas de vida em geral, reconhecendo valores fundamentais não apenas a vida humana,$^{73}$ mas a preservação de todos os recursos naturais ${ }^{74}$, incluindo as outras formas de existência. ${ }^{75}$

$\mathrm{O}$ constituinte brasileiro evidenciou a situação a qual os não-humanos eram submetidos, restando ciente de que diferentemente do homem, os demais animais são incapazes de tomar posição nas relações às quais estão envolvidos, não podendo defender seus interesses perante a humanidade. Construiu-se o mandamento

A. Pinto de Carvalho. São Paulo: Editora Nacional, 1964. p. 436. A razão refere assim toda máxima da vontade, concebida como legisladora universal, a toda outra vontade, e também a toda ação que o homem ponha para consigo: procede assim, não tendo em vista qualquer outro motivo prático ou vantagem futura, mas levada pela ideia da dignidade de um ser racional que não obedece a nenhuma outra lei que não seja, ao mesmo tempo, instituída por ele próprio. No reino dos fins tudo tem um PREÇO ou uma DIGNIDADE. Uma coisa que tem um preço pode ser substituída por qualquer outra coisa equivalente; pelo contrário, o que está acima de todo preço e, por conseguinte, o que não admite equivalente, é o que tem uma dignidade. [...] Ora, a moralidade é a única condição capaz de fazer com que um ser racional seja um fim em si, pois só mediante ela é possível ser um membro legislador no reino dos fins. Pelo que, a moralidade, bem como a humanidade, enquanto capaz de moralidade, são as únicas coisas que possuem dignidade.

72 Sobre este tema, ver: Cf. SILVA, Tagore Trajano de Almeida. LANGERHORST, Victor. \& BRAGA, Sérgio. Fundamentos do Direito Animal Constitucional. Revista Brasileira de Direito Animal. Ano 7. Vol. 10. jan/jun. p. 233274. 2012.

73 SARLET, Ingo Wolfgang. Dignidade da Pessoa Humana e Direitos Fundamentais na Constituição Federal de 1988. 5. ed. Porto Alegre: Livraria do Advogado, 2007. p. 34-35.

74 Hans Jonas defende uma dignidade da natureza que seria alcançada com a substituição dos antigos imperativos éticos, dentre os quais o imperativo kantiano. Devese passar do imperativo kantiano que determina um agir individual "[...] de modo que o princípio da tua ação se transforme em uma lei universal", para um novo imperativo, fundado na responsabilidade que atribui ao homem um agir responsável de maneira que "os efeitos de sua ação sejam compatíveis com a permanência da vida [...]”. Ver em: SIQUEIRA, José Eduardo de. El principio de responsabilidad de Hans Jonas. Acta bioeth., 2001, vol.7, no.2, p.277-285. ISSN 1726-569X. p. 279.

75 JONAS, Hans. El principio de responsabilidad: ensayo de una ética para la civilización tecnológica. Barcelona: Herder, 1995. Ver também em: SIQUEIRA, José Eduardo de. El principio de responsabilidad de Hans Jonas. In Acta bioeth., 2001, vol.7, no.2, p.277-285. ISSN 1726-569X. p. 279. 
constitucional da não-crueldade como uma forma de mudança de paradigma para lembrar à raça humana do dever de tratar os outros seres com dignidade, não como instrumentos, nem como escravos. ${ }^{76}$

Nesse sentido, ser cruel é tomado como uma violação da própria dignidade, cristalizando progressivamente uma fórmula da personalidade desses seres a informar que existe uma proibição direta ao tratamento insuficiente ou excessivo dirigido aos animais ${ }^{77}$. Evidencia-se que os seres humanos partilham uma relação moral comum com os demais seres do planeta, tendo deveres morais com eles ${ }^{78}$, uma vez que conscientes de sua dignidade e de sua consideração, têm a obrigação de tratar os outros seres através do mesmo status que almejam. ${ }^{79}$.

Este giro kantiano representa uma extensão da regra de ouro através de uma representação jurídica constitucional ${ }^{80}$, impondo que todos sejam tratados igualmente, independentemente das muitas diferenças, inclusive a biológica ${ }^{81} \mathrm{O}$ estabelecimento desta cláusula geral como um parâmetro ético-jurídico a orientar o direito permite estabelecer uma dignidade animal como valor-fonte da experiência axiológica do Direito Animal ${ }^{82}$.

A diferença e constatação de que os não-humanos têm um valor e não meramente é algo valorado ${ }^{83}$ molda a Carta de 1988 como um documento ímpar no cenário mundial, a figurar como um verdadeiro Estatuto Jurídico em favor de

76 MEDEIROS, Fernanda Luiza Fontoura de. Direito dos animais. Porto Alegre: Livraria do Advogado, 2013. p. 289.

77 HABERLE, Peter. A dignidade humana como fundamento da comunidade estatal. In: SARLET, Ingo Wolfgang (Org.). Dimensões da dignidade: ensaios de filosofia do direito e direito constitucional. 2. ed. Porto Alegre: Editora Livraria do Advogado, 2009. p. 89-152. p. 105.

78 Cf. FUKUYAMA, Francis. Nosso Futuro Pós-Humano: Consequências da Revolução da Biotecnologia. Trad. de Maria Luiza X. de A. Borges. Rio de Janeiro: Rocco, 2003. p. 23 e ss.

79 MEDEIROS, Fernanda Luiza Fontoura de. Direito dos animais. Porto Alegre: Livraria do Advogado, 2013. p. 289.

80 REGAN, Tom. Jaulas Vazias. Porto Alegre: Lugano, 2006. p. 52-53.

81 Como a regra de ouro da ética: "não devamos fazer com o outro aquilo que não queremos que nos façam na mesma situação" ou mesmo na tradição judaico-cristã: "Amai o vosso próximo como a vós mesmos". FELIPE, Sônia. Fundamentação ética dos direitos animais. O legado de Humphry Primatt. Revista Brasileira de Direito Animal. Vol. 01. Ano. 1. Salvador: Instituto Abolicionista Animal, 2006. p. 221.

82 SOARES, Ricardo Maurício Freire. O princípio constitucional da dignidade da pessoa humana: em busca do direito justo. São Paulo: Saraiva, 2010. p. 129.

83 ALEXY, Robert. Teoria dos Direitos Fundamentais. Trad. Virgílio Afonso da Silva. São Paulo: Malheiros, 2008. p. 146. 
direitos para os animais ${ }^{84}$.

Este encontro entre o direito e uma nova ética pós-humanista ocupa local de destaque na Constituição, em que os valores morais se convertem em princípios jurídicos, irradiando pelo sistema normativo como um todo, condicionando a interpretação e a aplicação de todo o direito infraconstitucional. ${ }^{85}$

A dignidade animal renova a relação entre o sistema de normas e o sistema de valores sociais, direcionando uma obrigação moral direta para com os animais ${ }^{86}$, um dever de pós-humanidade, em que aqueles que o sentem não são os principais responsáveis por tal sofrimento, não sendo certo tratá-los indignamente, visto terem direitos, um crédito moral de não serem tratados de tal modo.$^{87}$ Há um verdadeiro reconhecimento do valor inerente dos animais não-humanos ${ }^{88}$, asseverando seu status de sujeito-de-uma-vida. ${ }^{89}$

Questão a ser posta é: como compatibilizar o presente entendimento com aquele encontrado no artigo $1^{\circ}$, inciso III da Carta Magna que prevê a dignidade da pessoa humana como princípio fundamental do Estado brasileiro?

Observa-se que a resposta não é simples e advém do processo de interpretação sistêmica da própria Lei Fundamental ${ }^{90}$, porquanto: 1) os preceitos constitucionais devem incidir sobre todas as relações sociais; 2) não existem normas sobrando no texto da Carta de 1988, sendo todas vigentes e operativas, cabendo ao intérprete tão-somente descobrir o âmbito de incidência de cada uma; e, 3) não há conflitos reais entre as normas da Constituição, mas apenas conflitos aparentes, seja porque elas foram promulgadas conjuntamente, seja porque não existe hierarquia

$84 \quad$ REGAN, Tom. The case of animal rights. $2^{\mathrm{a}}$. ed. Califórnia: University of California Press, 2004. p. 267 e ss.

85 Cf. BARROSO, Luís Roberto. Neoconstitucionalismo e constitucionalização do Direito. Revista de Direito Administrativo. Rio de Janeiro, v. 240, p. 1-42, 2005.

86 RAWLS, John. Uma teoria de justiça. Trad. Almiro Pisetta e Lenita Maria Rímoli Esteves. $2^{\mathrm{a}}$ ed. São Paulo: Martins Fontes, 2002 p. 369-379.

87 NUSSBAUM, Martha C. Para além de compaixão e humanidade: justiça para animais não-humanos. In MOLINARO, Carlos Alberto; SARLET, Ingo Wolfgang. [et. al] (orgs.) A dignidade da vida e os direitos fundamentais para além dos humanos: uma discussão necessária. Belo Horizonte: Fórum, 2008. p. 85-126. p. 90-92.

88 REGAN, Tom. Jaulas Vazias. Porto Alegre: Lugano, 2006. p. 61.

89 FELIPE, Sônia T. Dos Direitos morais aos Direitos Constitucionais: Para além do especismo elitista e eletivo. Revista Brasileira de Direito Animal/Brazilian Animal Rights Review. Vol. 02. Ano. 1. Jan/Jun. p. 143-159. Salvador: Evolução, 2007. p. 146.

$90 \quad$ SILVA NETO, Manoel Jorge e. Curso de Direito Constitucional. 6 a .ed. Rio de Janeiro: Lúmen Júris, 2010. p. 124 e ss. 
nem ordem de precedência entre seus dispositivos. ${ }^{91}$

A dignidade da pessoa humana é um conceito jurídico indeterminado, pressuposto de intangibilidade da vida $^{92}$, pressupondo uma escolha não-seletiva de qual vida merece ou não maior atenção. Qualquer critério distintivo está fadado pelo especismo eletivo ${ }^{93}$, na medida em que escolhe determinadas categorias de animais para serem juridicamente protegidas em detrimento dos demais. ${ }^{94}$

A dignidade humana é princípio jurídico que, ao se concretizar, exige um trabalho de modelação para adaptação ao caso concreto, sendo necessário compatibilizar a dignidade de um ser com a do outro ${ }^{95}$ (e, portanto, alguma coisa da dignidade de um ser poderá ficar prejudicada pelas exigências da dignidade do outro $)^{96}$.

Esta concepção é fundamental para o estabelecimento da dignidade animal, não como "cheque em branco" na defesa dos não-humanos ${ }^{97}$, mas como um dever de proteção caracterizador da ampliação de um círculo hermenêutico pós-humanizado ${ }^{98}$, acolhedor das demais formas de vida que existem por si só, independentemente da

91 MENDES, Gilmar Ferreira. COELHO, Inocêncio Mártires. BRANCO, Paulo Gustavo Gonet. Curso de direito constitucional. 2.ed. São Paulo: Saraiva, 2008. p. 112-113.

92 AZEVEDO, Antônio Junqueira de. Caracterização jurídica da dignidade da pessoa humana. Revista dos Tribunais. Vol . 797. Ano. 91. p. 11-26. São Paulo: RT, Março de 2002. p. 19.

93 FELIPE, Sônia T. Dos Direitos morais aos Direitos Constitucionais: Para além do especismo elitista e eletivo. Revista Brasileira de Direito Animal/Brazilian Animal Rights Review. Vol. 02. Ano. 1. Jan/Jun. p. 143-159. Salvador: Evolução, 2007. p. 179.

94 LOURENÇO, Daniel. Direito dos Animais: fundamentação e novas perspectivas. Porto Alegre: Sergio Antonio Fabris, 2008. p. 491.

95 MACKINNON, Catharine A. Of Mice and Men: A Feminist Fragment on Animal Rights. In SUNSTEIN, Cass \& NUSSBAUM, Martha (eds). Animal Rights: current debates and new directions. p. 263-276. Oxford University Press, 2004. p. 271 e ss.

96 AZEVEDO, Antônio Junqueira de. Caracterização jurídica da dignidade da pessoa humana. Revista dos Tribunais. Vol . 797. Ano. 91. p. 11-26. São Paulo: RT, Março de 2002. p. 19.

97 SILVA, Tagore Trajano de Almeida. Animais em juízo. Salvador: Evolução, 2012. p. 137 e ss.

98 HABERLE, Peter. A dignidade humana como fundamento da comunidade estatal. In: SARLET, Ingo Wolfgang (Org.). Dimensões da dignidade: ensaios de filosofia do direito e direito constitucional. 2. ed. Porto Alegre: Editora Livraria do Advogado, 2009. p. 89-152. p. 127. 
vontade do homem..$^{99}$

A noção de dignidade sofre uma guinada epistemológica, pós-humanizando a Constituição e seus princípios, apresentando-se como norte interpretativo para todos aqueles detentores de direitos fundamentais ${ }^{100}$.

O novo rumo cognitivo derivado da Constituição evita a coisificação do não-humano ${ }^{101}$, evidenciando situações de exposição, exploração e menosprezo arbitrário desses seres ${ }^{102}$.

Nesse sentido, identifica-se uma porção delimitadora de bens protegidos pela cláusula geral da dignidade anima ${ }^{103}$, normatizados constitucionalmente e derivados da regra geral de não crueldade inserida no artigo $225, \S 1^{\circ}$, VII. A proteção da vida, integridade e da busca da subsistência dos não-humanos figurariam como objetos de um mandamento de otimização a caracterizar a aplicação de um direito fundamental pensado materialmente igual para todos os animais. ${ }^{104}$

Por este motivo, pode-se dizer que a Constituição de 1988 autoriza uma pós-humanização do ordenamento jurídico brasileiro, representando simbolicamente a superação de um modelo autoritário e excludente de Estado e sociedade. ${ }^{105}$ A Carta

99 GORDILHO, Heron José de Santana. Direito Ambiental pós-moderno. Curitiba: Juruá, 2009. p. 123 e ss.

100 BARCELlos, Ana Paula de. A eficácia Jurídica dos Princípios Constitucionais: O Princípio da Dignidade da Pessoa Humana. Rio de Janeiro: Renovar, 2002. p. 110.

101 MEDEIROS, Fernanda Luiza Fontoura de. Direito dos animais. Porto Alegre: Livraria do Advogado, 2013. p. 70.

102 Cf. HABERLE, Peter. A dignidade humana como fundamento da comunidade estatal. In: SARLET, Ingo Wolfgang (Org.). Dimensões da dignidade: ensaios de filosofia do direito e direito constitucional. 2. ed. Porto Alegre: Editora Livraria do Advogado, 2009. p. 89-152. p. 105.

103 Esse seria o melhor entendimento, pois a dignidade animal seria o gênero a englobar a dignidade humana, uma vez que com base em uma interpretação evolutiva deste princípio poderia se afirmar que existiria um verdadeiro pleonasmo ao se falar sobre dignidade animal, já que todos os animais seriam detentores de um valor intrínseco. Sobre o tema, ver: GORDILHO, Heron José de Santana \& SILVA, Tagore Trajano de Almeida. Animais em Juízo: direito, personalidade jurídica e capacidade processual. Revista de Direito Ambiental. Vol. 65. p. 333-363, 2012.

104 Cf. GORDILHO, Heron José de Santana \& SILVA, Tagore Trajano de Almeida. Habeas Corpus para os grandes primatas. Revista do Instituto do Direito Brasileiro da Faculdade de Direito da Universidade de Lisboa-RIDB. Vol. 04. p. 2077-2114, 2012.

105 Cf. SARMENTO, Daniel. Ubiquidade constitucional: os dois lados da moeda. Livres e iguais: estudos de direito constitucional. Rio de Janeiro: Lumen 
Cidadã deixou espaço para um aperfeiçoamento constante de seu texto, irradiando valores (ausstrahlend) basilares para o campo do Direito Animal a orientar uma nova postura por parte dos operadores do direito. ${ }^{106}$

\subsection{O antiespecismo como valor concretizador da igualdade material}

Em 1935, Sobral Pinto utilizou as leis de proteção aos animais da época para livrar Luiz Carlos Prestes e Harry Berger de condições subumanas as quais estavam submetidos na prisão pela ditadura de Getúlio Vargas. Alegava, em sua defesa, que seus clientes deveriam ser tratados em igualdade de condições àquelas impostas aos animais ${ }^{107}$. A proposta agora se inverte. A Constituição brasileira indica haver uma extensão do princípio de igualdade para além da espécie humana sob fortes bases ético-filosóficas. ${ }^{108}$

Richard Ryder foi o responsável por estabelecer um paralelo da relação à qual se encontram submetidos os animais com as diversas outras formas de discriminação visualizadas na sociedade ${ }^{109}$. Para Ryder, não se pode utilizar critérios relacionados com a aparência física, a raça, a religião ${ }^{110}$, o gênero ou mesmo a

Juris, 2010. p. 177 e ss.

106 KRELL, Andreas J. Direitos Sociais e Controle Judicial no Brasil e na Alemanha - os (des)caminhos de um Direito Constitucional "comparado". Porto Alegre: Sergio Antonio Fabris Editor, 2002. p. 81.

107 VENÂNCIO FILHO, Alberto. Sobral Pinto, o Advogado. Revista da EMERJ. Vol. 12, no 45, p. 195-203, 2009. p. 198.

108 Esse foi o entendimento do ex-Ministro do Supremo Tribunal Federal, Antônio Cézar Peluso, em voto dissidente, no julgamento da ADPF 54 (anencefalia). Sem entrar no mérito da decisão, observa-se uma verdadeira pós-humanização da norma constitucional por seu intérprete ao conceber o especismo como uma forma de discriminação vedada pela própria Carta Constitucional brasileira, in verbis: "Ao feto, reduzido no fim das contas à condição de lixo ou de outra coisa imprestável e incômoda, não é dispensada de nenhum ângulo a menor consideração ética ou jurídica nem reconhecido grau algum da dignidade jurídica que lhe vem da incontestável ascendência e natureza humana. Essa forma de discriminação em nada difere, a meu ver, do racismo e do sexismo e do chamado especismo. Todos esses casos retratam a absurda defesa em absolvição da superioridade de alguns, em regra brancos de estirpe ariana, homens e ser humanos, sobre outros, negros, judeus, mulheres e animais".

109 RYDER, Richard. Speciesism and 'painism'. The Animal's Agenda. 1997. p. 45.

110 Sobre este tema, ver: OLIVEIRA, Fábio Corrêa Souza de. Especismo religioso. Revista Brasileira de Direito Animal. Vol. 08. Ano 06. p. 161- 220. Jan/ Jun. Salvador: Evolução, 2011. 
espécie, para formular categorizações entre interesses humanos e não-humanos. Há um paralelismo moral entre especismo, racismo, sexismo e outros "-ismos" sociais. ${ }^{111}$

O princípio constitucional do antiespecismo implica dizer que a preocupação com os outros não deve depender de como são ou das aptidões que possuem ${ }^{112}$. $\mathrm{O}$ fato de algumas pessoas não serem membros da espécie humana não dá o direito de explorá-los, nem significa que se possa deixar de levá-los em consideração. ${ }^{113}$

Como visto no primeiro capítulo, filosoficamente, duas são as correntes que trabalham o conteúdo da igualdade: 1) o utilitarismo com a igual consideração de interesses, defendida por Peter Singer; e 2) a teoria dos direitos morais de Tom Regan. ${ }^{114}$

O utilitarismo filosófico de Singer fundamenta-se em Jeremy Bentham (1748-1832), asseverando no livro Uma introdução aos princípios da moral e da legislação, ${ }^{115}$ que a ética deveria se estender a aplicação do princípio da igualdade

111 Sobre uma crítica deste posicionamento, ver: NACONECY, Carlos M. As (des)analogias entre racismo e especismo. Revista Brasileira de Direito Animal. Vol. 06. Ano. 05. p. 173-208. Jan/Jun. Salvador: Evolução, 2010. p. 171.

112 Peter Singer pontua a dificuldade na compreensão deste entendimento, ao dizer ainda no início do movimento pela libertação animal que: "É provável que o leitor seja cético. 'Libertação Animal' soa mais como uma paródia dos movimentos de libertação do que como um objetivo sério. O leitor pode pensar: Nós apoiamos as reivindicações de negros e mulheres pela igualdade, porque os negros e as mulheres realmente são iguais aos brancos e machos, iguais em inteligência e em suas habilidades, capacidade de liderança, a racionalidade, e assim por diante. Os seres humanos e não-humanos, obviamente, não são iguais nestes aspectos. Uma vez que a justiça exige apenas que tratar iguais de forma igual, o tratamento desigual dos seres humanos e não-humanos não pode ser uma injustiça". SINGER, Peter. Animal liberation. The New York Review of Books. Vol. 20. No 05. Published in 05 de Abril de 1973.

113 SINGER, Peter. Ética prática. Trad. Jefferson Luís Camargo. 3a ed. São Paulo: Martins Fontes, 2006. p. 66.

114 Sobre este tema, ver o trabalho comparando as duas teorias: SILVA, Tagore Trajano de Almeida. Afirmação histórica dos direitos dos animais à luz dos trabalhos de Peter Singer e Tom Regan. In: Anais do $16^{\circ}$ Congresso Internacional de Direito Ambiental, o $6^{\circ}$ Congresso de Direito Ambiental dos Países de Língua Portuguesa e Espanhola e o $6^{\circ}$ Congresso de Estudantes de Direito Ambiental - PNMA: 30 anos da Política Nacional de Meio Ambiente. São Paulo: Imprensa Oficial do Estado de São Paulo, 2011. v. 01. p. 635-642.

115 BENTHAM, Jeremy. An Introduction to the Principles of Morals and Legislation. In two volumes. London: W. Pickering, Linconln's inn fields and E. Wilson, Royal Exchange, 1823. Primeira edição impressa em 1780 e publicada em 1789. 
de consideração moral a todos os seres dotados de sensibilidade, ou seja, capazes de sofrer. ${ }^{116}$

A capacidade de buscar o prazer e se afastar da dor é o pré-requisito para se ter algum interesse, sendo encontrada apenas nos seres sencientes, ${ }^{117}$ os quais possuem pelo menos uma forma de interesse - o de não sofrer ${ }^{118}$.

Tom Regan avança na concepção de direitos morais dirigidos aos animais, ampliando o conceito kantiano de dignidade para modificar o status moral dos animais, considerando-os como sujeitos-de-uma-vida (subject of a life ${ }^{119}$. Regan

116 A célebre citação de Bentham na defesa da libertação animal ensina que: "Chegará o dia em que o restante da criação animal venha a adquirir os direitos que nunca poderiam ter sido negados aos animais, a não ser pela mão da tirania. Os franceses já descobriram que a cor negra da pele não é razão para que um ser humano seja irremediavelmente abandonado aos caprichos do torturador. Haverá o dia que se reconheça que o número de pernas, a vilosidade [villosity] da pele ou a terminação do osso sacro são razões igualmente insuficientes para abandonar um ser senciente ao mesmo destino. O que mais deveria traçar a linha intransponível? A faculdade da razão, ou, talvez, a capacidade do discurso? Mas um cavalo ou um cão adultos são incomparavelmente mais racionais e comunicativos de que um bebê de um dia, uma semana, ou até mesmo de um mês. Supondo, porém, que as coisas não fossem assim, que importância teria tal fato? A questão não é: eles podem raciocinar?, nem, eles podem falar?, mas, sim: eles podem sofrer?" BENTHAM, Jeremy. An Introduction to the Principles of Morals and Legislation. Op. cit. p. 235-236.

117 BENTHAM, Jeremy. An Introduction to the Principles of Morals and Legislation. Op. cit. p. 235-236.

118 [...] Se um ser sofre, não pode haver nenhuma justificativa de ordem moral para nos recusarmos a levar esse sofrimento em consideração. Seja qual for a natureza do ser, o princípio de igualdade exige que o sofrimento seja levado em conta em termos de igualdade com o sofrimento semelhante - até onde possamos fazer comparações aproximadas - de qualquer outro ser. Quando um ser não for capaz de sofrer, nem de sentir alegria ou felicidade, não haverá nada a ser levado em consideração. É por esse motivo que o limite de sensibilidade é o único limite defensável da preocupação com os interesses alheios. Demarcar esse limite através de uma característica, como a inteligência ou a racionalidade, equivaleria a demarcála de modo arbitrário. Por que não escolher alguma outra característica, como, por exemplo, a cor da pele? SINGER, Peter. All animals are equal. In: Defense of animals: the second wave. Oxford: Blackwell, 2006. p. 154.

119 Nesse sentido, leciona Regan: "Como sujeitos-de-uma-vida, somos todos iguais porque estamos todos no mundo. Como sujeitos-de-uma-vida, somos todos iguais porque somos todos conscientes do mundo. Como sujeitos-de-uma-vida, somos todos iguais porque o que acontece conosco é importante para nós. Como sujeitos-de-uma-vida, somos todos iguais porque o que acontece conosco (com 
parte da tradição humanista de Kant para ampliar a comunidade moral para além dos animais humanos, garantindo aos não-humanos direitos básicos, tais como: vida, integridade física e liberdade ${ }^{120}$. Para Regan, direitos não são apenas aqueles reconhecidos pelas normas existentes, dependem igualmente da correlação com os deveres e, principalmente, com o modo que a sociedade os estabelece. ${ }^{121}$

As duas teorias são importantes para a delimitação do conteúdo jurídico do princípio do antiespecismo, ao se levar em conta à evolução histórica da moralidade de cada sociedade, isto é, avança-se da consideração dos interesses dos animais até a tomada de conscientização de uma dignidade animal, consagrando uma teoria que delimita direitos fundamentais para todos: humanos e não-humanos. ${ }^{122}$

A compreensão evolutiva dos conceitos jurídicos é fundamento do Direito Animal, uma vez que esta visão corrobora para o continuum jurídico e moral percebido em fenômenos sociais dos mais diversos, seja nos momentos de abolição da escravatura, como também no reconhecimento do voto feminino, na atribuição de direitos às crianças e aos deficientes, além da eliminação do colonialismo ${ }^{123}$ e de outras formas de imperialismo. ${ }^{124}$

A evolução da perspectiva em torno dos animais garante uma Constituição aberta a novos valores, dinâmica ${ }^{125}$, preservando seu espírito democrático e

nossos próprios corpos, nossa liberdade ou nossas vidas) é importante para nós, quer os outros se preocupem com isso, quer não. Como sujeitos-de-uma-vida, não há superior nem inferior, não há melhores nem piores. Como sujeitos-de-umavida, somos todos moralmente idênticos. Como sujeitos-de-uma-vida, somos todos moralmente iguais". REGAN, Tom. Jaulas Vazias. Porto Alegre: Lugano, 2006. p. 62.

120 BEKOFF, Marc, and CARRON Meaney. Encyclopedia of Animal Rights and Animal Welfare. Westport, CT: Greenwood Publishing Group, Inc., 1998. p. 43. 121 MILL, John Stuart. Utilitarianism. 2 ${ }^{\mathrm{a}}$. ed. Longmans, Green, Reader \& Dyer, 1863. p. 79.

122 CHALFUN, Mery. Paradigmas filosóficos - ambientais e o direito dos animais. Revista Brasileira de Direito Animal. Vol. 06. p. 209-246. Jan/Jun. Salvador: Evolução, 2010. p. 210.

123 Sobre o tema, ver, dentre outros, DAMATTA, Roberto. Carnavais, Malandros e Herois. Rio de Janeiro: Rocco, 1997. p. 171 e ss.

124 WALDAU, Paul. The Specter of Speciesism: Buddhist and Christian Views of Animals. Oxford and New York: Oxford University Press, 2002. p. 28.

125 Joaquim Barbosa compartilha a percepção do dinamismo da interpretação do princípio da igualdade, ensinando que "em lugar da concepção "estática" da igualdade extraída das revoluções francesa e americana, cuida-se nos dias atuais de se consolidar a noção de igualdade material ou substancial, que, longe de se apegar ao formalismo e à abstração da concepção igualitária do pensamento liberal oitocentista, 
reorientando continuamente a interpretação/aplicação da Carta em vigor. ${ }^{126}$ De fato, a Constituição brasileira, ao estabelecer no caput de seu artigo $5^{\circ}$, que todos são iguais perante a lei, não discrimina os destinatários da Lei Fundamental, deixando a cargo da doutrina e do legislador este papel ${ }^{127}$.

Curioso é perceber que os intérpretes da Carta Política apenas dirigem sua energia para os interesses de seu grupo, um reflexo no espelho, afirmando um narcisismo intelectual não condizente com o espírito constitucional. ${ }^{128}$

O princípio antiespecista garante uma igualdade perante a lei, sem discriminações ou favoritismos interespécies, bem como combate formas de desigualdade na própria lei, a ser observado no momento de valoração de todos os atos normativos que submetam os não-humanos à crueldade, sintoma que macula a norma com o sinal de inconstitucionalidade ${ }^{129}$.

Não se quer aqui dizer que a Constituição fecha os olhos para situações em que diferenciações são toleráveis ${ }^{130}$, isso porque humanos e não-humanos não são

recomenda, inversamente, uma noção 'dinâmica', 'militante' de igualdade, na qual necessariamente são devidamente pesadas e avaliadas as desigualdades concretas existentes na sociedade, de sorte que as situações desiguais sejam tratadas de maneira dessemelhante, evitando se assim o aprofundamento e a perpetuação de desigualdades engendradas pela própria sociedade”. GOMES, Joaquim B. Barbosa. A recepção do instituto da ação afirmativa pelo Direito. Constitucional Brasileiro. Revista de Informação Legislativa. Brasília, a.38. n. 151 jul./set. 2001. p. 131.

126 MIRANDA, Jorge. Manual de direito constitucional. Tomo II: Constituição. $6^{\text {a }}$ ed. Coimbra: Coimbra, 2007. p. 172.

127 Cármen Lúcia Rocha pontifica que coube à doutrina o grande mérito de haurir do princípio negador da validade do preconceito, como motivo de ação aceitável no Direito, o princípio maior da igualdade, alargando na terminologia do princípio o que não se continha em seu conteúdo e nas normas jurídicas que lhe fixavam o conteúdo e a forma de aplicação. ROCHA, Cármen Lúcia Antunes. Ação Afirmativa: o conteúdo democrático do princípio da igualdade jurídica. Revista de Informação Legislativa. Vol. 33. n 131. p. 283-295, jul./set. de 1996. p. 284.

128 Sobre este tema, ver, debate sobre o conceito de alguém exposto em: GORDILHO, Heron José de Santana; SANTANA, Luciano Rocha; SILVA, Tagore Trajano de A.. [et. al]. Habeas Corpus impetrado em favor da chimpanzé Suíça na 9a Vara Criminal de Salvador (BA). Revista Brasileira de Direito Animal. Vol. 01. Ano. 01. Jan/Dez. Salvador: Instituto de Abolicionismo Animal, 2006.

129 SARMENTO, Daniel. Livres e Iguais: Estudos de Direito Constitucional. Rio de Janeiro: Lumen Juris, 2006. p. 145.

130 Nesse sentido Hans Kelsen ensina que: “A igualdade dos indivíduos sujeitos à ordem jurídica, garantida pela Constituição, não significa que aqueles devam ser tratados por forma igual nas normas legisladas com fundamento na Constituição, especialmente nas leis. Não pode ser uma tal igualdade aquela que se tem em vista, 
seres idênticos ${ }^{131}$, porém para que haja um discrímen jurídico deve existir uma razão valiosa condizente com a vontade da própria Carta Política ${ }^{132}$.

O que se tem pela regra do artigo $225, \S 1^{\circ}$, inciso VII da Constituição da República, é o escudo protetivo da dignidade animal, sendo o princípio do antiespecismo uma das vertentes a balizar uma postura pós-humanista de interpretação/ aplicação do texto constitucional que se amplia para ir além da fronteira humana. Isto não quer dizer que haja uma preponderância dos direitos dos não-humanos sobre os direitos humanos. Em verdade, afirma-se um só Direito, Direito Animal, sem artificialidades ${ }^{133}$, a salvaguardar, agora sim, todos os seres no planeta, moldando o conteúdo jurídico do princípio do antiespecismo, fundamento para uma justiça social interespécies ${ }^{134}$.

\subsection{A não-violência como forma de pacificação interespécies}

O Brasil é um dos maiores exportadores de produtos derivados de origem animal, sendo também, junto com os Estados Unidos, Japão e China, um dos maiores consumidores mundiais de carne ${ }^{135}$. Nos estabelecimentos destinados a este tipo de comércio, segundo o Instituto Brasileiro de Geografia e Estatística - IBGE, o país tem registrado recordes históricos de abate de animais com mais de 50 milhões de bois, porcos, ovelhas e bodes criados e abatidos, por ano, sendo, no caso das aves de

pois seria absurdo impor os mesmos deveres e conferir os mesmos direitos a todos os indivíduos sem fazer quaisquer distinções, por exemplo, entre crianças e adultos, sãos de espírito e doentes mentais, homens e mulheres". KELSEN, Hans, Teoria pura do direito. Trad. João Baptista Machado. 6 ed. São Paulo: Martins Fontes, 1998. p. 99.

131 Ver sobre o princípio ético da igual consideração de interesses: SILVA, Tagore Trajano de Almeida. Introdução aos direitos dos animais. Revista de Direito Ambiental. Vol. 62. p. 141-168, 2011.

132 MELLO, Celso Antônio Bandeira de. Conteúdo Jurídico do Princípio da Igualdade. 3a ed. São Paulo: Malheiros, 2004. p. 41.

133 DAWKINS, Richard. Gaps in the Mind. In CAVALIERI, Paola \& SINGER, Peter (Ed). The Great Ape Project.: Equality Beyond Humanity, New York: St. Martin's Press, 1993. p. 81.

134 Ver, sobre uma perpectiva diferente, BARILAN, Y. Michael. Speciesism as a Precondition to Justice. Politics and the Life Sciences. Vol. 23. N ${ }^{\circ}$. 01. p. 22-33. Mar, 2004. p. 29.

135 Ver, dentre outras reportagens: Brasil bate recorde de abate no $1^{\circ}$ trimestre. Publicada em 25 de junho 2013 às 07:05. Disponível em: http://www.portaldbo.com. br/Portal/Conteudo/Noticias/7101 „Brasil+bate+recorde+de+abate+no+1+trimestre. aspx. Acessado em: 01 de julho de 2013. 
produção, como as galinhas, mais de cinco bilhões no mesmo período ${ }^{136}$.

Em geral, a população desconhece o que acontece na indústria alimentícia. A forma violenta com que os animais são tratados, seus métodos a reduzir os custos e aumentar a produção, as linhas de montagem de criação industrial; todos a tratar os animais como objetos e números para o consumo humano ${ }^{137}$.

A indiferença artificialmente produzida em supermercados, restaurantes e açougues produz uma espécie de "banalização do mal" na relação entre humanos e não-humanos, gerando uma incapacidade de pensar e julgar que o alimento consumido é resultado da dor e sofrimento do animal ${ }^{138}$. Não é por outro motivo que se substitui a imagem da criação de animais em locais inapropriados e de forma intensiva por imagens de galinhas alegres e cantantes, bois felizes ao serem mortos, além de ovelhas contentes esperando o abate ${ }^{139}$.

Estes disfarces verbais impossibilitam uma real tomada de posição por parte dos cidadãos que ignoram a dor sofrida pelos animais, o transporte inadequado a que são submetidos, além das outras formas de violência a estimular comparações com períodos indesejados da humanidade, tais como os campos de concentração nazistas e os porões dos navios negreiros ${ }^{140}$.

Esta sucinta análise manifesta uma desconformidade da realidade com a

136 Sobre o número de animais abatidos por ano e por unidade da federação no Brasil, ver: Indicadores IBGE: Estatística da Produção Pecuária. Março de 2013. Disponível em: http://www.ibge.gov.br/home/estatistica/indicadores/agropecuaria/ producaoagropecuaria/abate-leite-couro-ovos_201204_publ_completa.pdf. Acessado em: 01 de junho de 2013.

137 Sobre o tema, ver o histórico trabalho de: HARRISON, Ruth. Animal Machine. Londres: Vicent Stuart, 1964.

138 Hannah Arendt cunha a expressão "a banalidade do mal" para caracterizar as ações de Eichmann como um membro do regime nazista. Sua caracterização destas ações não são consequências de uma "banalidade", mas da incapacidade de pensar e julgar a partir de uma valoração do outro. Cf. ARENDT, Hannah. Eichmman em Jerusalém: Um relato sobre a banalidade do mal. São Paulo: Companhia das Letras; 1999. p. 121.

139 Sobre este tema ver estudo de ABOGLIO, Ana Maria. Técnicas de apropiación discursiva. Disponível em: http://www.anima.org.ar/liberacion/ enfoques/tecnicas-apropiacion-discursiva.html. Acessado em: 05 de julho de 2013. Ver também: LOURENCO, Daniel Braga. Direito de imagem para animais? Publicado em: 22 de março de 2010 às 17:56. Disponível em: http://www.anda.jor. br/22/03/2010/direito-de-imagem-para-animais. Acessado em: 10 de julho de 2013.

140 Ver, dentre outros, sobre a evolução do tratamento dos animais nãohumanos: KEAN, Hilda. Animal rights: political and social change in Britain since 1800, Reaktion Books, 1998. 
vontade da Constituição que veda o tratamento cruel dos animais não-humanos ${ }^{141}$. O Estado brasileiro considera todo ato de crueldade como uma violação à dignidade, adotando uma postura institucional de não-violência na defesa dos direitos fundamentais ${ }^{142}$.

Como já foi tratado, configura uma postura especista eivada de inconstitucionalidade a interpretação que despreza a necessidade do tratamento não cruel a ignorar a dignidade dos seres dentro de centros industriais de produção animal, onde são submetidos ao confinamento intensivo, instrumentalizando a vida destes $\operatorname{seres}^{143}$.

Historicamente, a sociedade ocidental vem sendo construída através de episódios fisicamente destrutivos, onde conflitos violentos e guerras surgem como principal base para o nascimento de novas realidades sociais, sistemas políticos e relacionamentos entre cidadãos ${ }^{144}$. A prática da não-violência é um fator importante no nascimento de um novo sistema social que busque a redistribuição de poder junto com uma reconstrução política e jurídica do Estado ${ }^{145}$.

A ação não-violenta é uma técnica usada para combater poderes institucionalizados que dificilmente seriam depostos, pois se encontram completamente enraizados na comunidade. Diversas são as técnicas utilizadas, bastando que não cause dor ou dano físico a outrem como, por exemplo: cantar, marchar, pintura como forma de protesto, dar às costas, vaiar, recusar-se a fazer algo, protestos, boicotes, não-cooperação, deixar-se prender e intervenções de espaços são as mais utilizadas ${ }^{146}$.

141 Sobre o conceito de crueldade ver: CUSTÓDIO, Helita Barreira. Crueldade contra animais e a proteção destes como relevante questão jurídico-ambiental e Constitucional. Revista de Direito Ambiental. Vol. 10. abril/junho. São Paulo: Revista dos Tribunais, 1997. p. 65 e ss.

142 FOLEY, Conor. Combate à tortura: Manual para magistrados e membros do Ministério Público. Reino Unido: Human Rights Centre, University of Essex, 2003. p. 143.

143 Cf. HABERLE, Peter. A dignidade humana como fundamento da comunidade estatal. In: SARLET, Ingo Wolfgang (Org.). Dimensões da dignidade: ensaios de filosofia do direito e direito constitucional. 2. ed. Porto Alegre: Editora Livraria do Advogado, 2009. p. 89-152. p. 105.

144 BRUYN, Severyn T. Review of Politics of Nonviolent Action by Gene Sharp. American Journal of Sociology. Vol. 80:3. p. 795-798. Chicago: University of Chicago Press, 1974. p. 797.

145 Sobre este tema ver o trabalho de: SHARP, Gene. The Politics of Nonviolent Action. Boston: Porter Sargent, 1973.

146 GARVER, Eugene. Review of Politics of Nonviolent Action by Gene Sharp. Ethics. Vol: 84:3. p. 266-273. Chicago: University of Chicago Press, 1974. p. 267. 
Estes procedimentos utilizados em grandes mudanças sociais, apesar de pacíficos, são vistos distorcidamente pelas autoridades como forma de agressão às instituições democráticas ${ }^{147}$ as quais são governadas pelas mais diversas formas de poder social ${ }^{148}$.

Com efeito, ao desenvolver o ideal da satyagraha, Mohandas Karamchand Gandhi (Mahatma Gandhi) ensinou que a luta pelos direitos civis fundamenta-se sob duas bandeiras: a busca da verdade e a prática da não-violência (ahimsa) ${ }^{149}$. Esta concepção é incorporada pelo Constitucionalismo brasileiro, no artigo 225, §1 ${ }^{\circ}$, inciso VII, como uma forma de direito de resistência a garantir que todos os seres vivos têm certos direitos irrevogáveis e inalienáveis, que lhes são inerentes, não podendo sofrer opressão, além de pontuar a necessidade de defesa destes direitos pelo Estado, não permitindo violação institucional ou de particulares ${ }^{150}$.

A dimensão inserida por Gandhi influenciou os trabalhos de Martin Luther King, Jr. e Rosa Parks durante a campanha pelos direitos civis nos Estados Unidos da América, Bacha Khan na luta contra a colonização britânica na Índia e Nelson Mandela pelo fim do apartheid na África do Sul. ${ }^{151}$

A compreensão do princípio da não-violência corrobora com a filosofia que busca direitos para os animais, porquanto deixa claro uma postura de pacificação interespécies. O objetivo é esclarecer a população do mal que se causa aos animais, possibilitando, a cada indivíduo, uma tomada de posição. Esta atitude evita qualquer erro de interpretação ao relacionar as diversas formas de manifestação popular com violência, ou até mesmo terrorismo ${ }^{152}$. A utilização de ações diretas em defesa do

147 Cf. DWORKIN, Ronald. Levando os direitos a sério. Trad. Nelson Boeira. 2 ed. São Paulo: Martins Fontes, 2007. p. 317.

148 Sobre o conteúdo sociológico da Carta Constitucional, ver: LASSALLE, Ferdinand. A Essência da Constituição. 6ª ed. Rio de Janeiro, Lumen Juris, 2001 e LASSALE, Ferdinand. O que é uma Constituição. Belo Horizonte: Ed. Líder, 2002.

149 Satyagraha significa a 'força da verdade'. Gandhi usava a expressão para descrever uma forma de luta não-violenta, que inclui: a formulação de demandas, persuasão, negociação e, quando necessário, a ação direta, incluindo não-cooperação e a desobediência civil. Ver: LEUBSDORF, John. Gandhi's legal ethics. Rutgers Law Review. Vol. 51. p. 923-939. 1998-1999. p. 928.

150 BUZANELLO, José Carlos. Direito de resistência constitucional. Brasília: América Jurídica, 2003. p. 84.

151 Referências sobre a vida de Gandhi e Martin Luther King Jr. podem ser encontradas nas obras de: PASTAN, Amy. Gandhi: A photographic story of a life. DK Publishing, 2006; e PASTAN, Amy. Martin Luther King, Jr.: A photographic story of a life. DK Publishing, 2004.

152 Sobre a tentativa que relacionar o trabalho realizado por ativistas do movimento animal como terroristas, ver: BEST, Steven \& NOCELLA II, Anthony J. 
ideal, direito ou filosofia não pode significar sinônimo de ilegitimidade ${ }^{153}$.

Como em toda mudança de perspectiva, ações mais enérgicas, às vezes são inevitáveis ${ }^{154}$, contudo não se pode iniciar um processo de conscientização pela dignidade de humanos e não-humanos com violência, abusos ou agressões sob pena de deslegitimação social e marginalização do movimento. A radicalização tem que ser pacífica, com ideias e educação constante (satyagraha). Pode ser que demore, mas o ideal ahimsa é de, acordo com a história, o mais eficaz para uma reviravolta definitiva dos valores sociais, pois possibilita uma tomada de atitude por todos os membros da sociedade na busca de paz e equilíbrio interespécies ${ }^{155}$.

O princípio da não-violência fundamenta o Direito Animal por apontar na direção de um respeito entre humanos e não-humanos, estabelecendo um entendimento mútuo direcionado à justiça social ${ }^{156}$. Esta somente será atingida através de mudanças positivas na percepção pública dos animais não-humanos, reconhecendo os direitos destes seres e, sobretudo não os concebendo como objetos de prazer, pesquisa, entretenimento, ou seja, exploração por parte do homem ${ }^{157}$.

A transformação de comportamento produzida pela conduta pacifista indica o caminho para ações cotidianas dirigidas em prol dos não-humanos. Junto com outras preocupações éticas relacionadas a saúde, estética, religião e bem-estar dos indivíduos, a não exploração dos não-humanos tornar-se-á um valor social a ser também considerado pelo sistema jurídico ${ }^{158}$.

Defining Terrorism. Animals Liberation Philosophy and Policy Journal. Vol.02. p. 56-72. Issue 1, 2004. p. 56.

153 BRYANT, Taimie L. Mythic Non-violence. Journal of Animal Law. Vol. 02. p. 01-13. 2006. p. 09.

154 REGAN, Tom. How to Justify Violence. In BEST, Steven \& NOCELLA II, Anthony J. Terrorists or Freedom Fighters? Reflections on the Liberation of animals. 2004. p. 235.

155 LIEBMAN, Matthew. I Fought the Law: a review of terrorists or freedom fighters? Reflections on the Liberation of Animals, edited by Steven Best \& Anthony J. Nocella II. Journal of Animal Law. Vol. 01. p. 151-169. 2005. p. 161.

156 Ver sobre o conceito de justiça: SILVA, Tagore Trajano de Almeida; GORDILHO, Heron José de Santana. Eficácia dos direitos fundamentais e justiça distributiva: o interesse público como problema jurídico nos tratamentos de saúde. Jurispoiesis (Rio de Janeiro). Vol. 14. p. 149-176, 2011.

157 Ver, nesse sentido, o texto de: STALLWOOD, Kim. A Personal Overview of Direct Action in the United Kingdom and the United States, In BEST, Steven \& NOCELLA II, Anthony J. Terrorists or Freedom Fighters? Reflections on the Liberation of animals. p. 81-93. 2004.

158 WALDAU, Paul. Will the heavens fall? De-radicalizing the precedentbreaking decision. Animal Law. Vol. 07. p. 75-117. 2001. p. 98. 


\subsection{Veganismo como compromisso moral com a emancipação pós-humanista}

O princípio do veganismo evidencia que o reconhecimento do Direito Animal possibilita uma mudança de atitudes globais e individuais em favor do planeta. Em âmbito individual, estabelece-se uma nova agenda a defender uma mudança substancial de atitude em defesa dos não-humanos como uma forma de compromisso político e ético a ser incorporado pela ciência jurídica ${ }^{159}$. No plano global, há um evidente direcionamento para uma real mudança de paradigma, a avançar além de posturas benestaristas em direção a uma perceptiva abolicionista de defesa dos animais. Existe uma rejeição à condição instrumental do animal, reconhecendo o seu valor inerente ${ }^{160}$.

Em geral, ao se falar em veganismo, estabelece-se uma relação com uma dieta alimentar rígida, sem a manipulação de animais, esquecendo ser este comportamento fundamental para a proteção dos não-humanos de conjunturas aviltantes ${ }^{161}$ como, e.g., o Concentrated Animal Feeding Operations (CAFOs) ${ }^{162}$.

Durante muitos anos, afirmou-se que a exportação e a prática de criação intensiva de animais em cativeiro tinham como objetivo alimentar a população crescente do planeta, prevenindo males como os da fome e da desnutrição das comunidades mais pobres. Criou-se uma fábula no sentido de que a sobrevivência dos seres humanos depende do consumo de outros animais, fornecedores de proteínas, acobertando formas de dor e opressão causadas aos não-humanos ${ }^{163}$.

159 FRANCIONE, Gary L. Reflections on animals, property, and the law and rain without thunder. Law and Contemporary Problems. Vol. 70. p. 09-57. Winter 2007. p. 41-43.

160 FRANCIONE, Gary L. Taking Sentience Seriously. Journal of Animal Law and Ethics. Vol. 01. p. 01-18. May, 2006. p. 18.

161 Ver, nesse sentido, GORDILHO, Heron José de Santana. Abolicionismo Animal. Revista de Direito Ambiental. Vol. 36. p. 85-109, 2004.

162 David Cassuto informa que a agricultura industrial é um dos principais contribuintes para emissões de gases prejudiciais a Terra. A atividade pecuária industrial emite quantidades significativas (e crescente) não apenas de dióxido de carbono, mas também gases de efeito estufa, incluindo o óxido nitroso (N2O) e metano (CH2). Na verdade, o efeito estufa as emissões de gases provenientes da agricultura excedem em muito os do transporte. No entanto, por razões culturais e políticas, a agricultura continua a não ser regulamentada. CASSUTO, David N. The CAFO Hothouse: Climate Change, Industrial Agriculture and the Law. Policy Paper. Ann Arbor, MI: Animals and Society Institute, 2010. p. 01.

163 Sobre o tema, ver: WINCKLER, Marly. Fundamentos do Vegetarianismo. Rio de Janeiro: Expressão e Cultura, 2004. 
Ser vegetariano ou vegano ${ }^{164}$ transformou-se em sinônimo de radicalismo, não se observando que seus seguidores na verdade lutam por uma maior transparência, justiça, pós-humanidade, responsabilidade social e preservação da vida dos animais ${ }^{165}$. A intolerância tem gerado um efeito prejudicial para a defesa dos animais, estimulando uma disputa não saudável entre os que são a favor e os que são contra a proteção desses seres ${ }^{166}$.

O processo de conscientização não é linear, não podendo afirmar que posturas benestaristas não contribuem para o fim do status de propriedade dos animais, nem mesmo que a postura vegana é uma quimera não condizente com a realidade dos povos ocidentais. As duas compreensões equivocam-se ao compreender a realidade de forma cumulativa e gradua ${ }^{167}$.

De fato, o princípio do veganismo corrobora ao elucidar que há um defeito estrutural na posição assistencialista da agenda pelo bem-estar animal, uma vez que gera uma conduta inconsistente por parte de seus defensores ao pensar que jaulas maiores significam jaulas vazias ${ }^{168}$.

164 Segundo Sarah Soifer, pode-se afirmar que vegan ou veganos são um subconjunto das inúmeras variedades de vegetarianos que adotam uma postura de não consumir, usar ou vestir qualquer produtos de origem animal. Sobre o tema ver: SOIFER, Sarah. Vegan Discrimination: an Emerging and Difficult Dilemma. Loyola of Los Angeles Law Review. Vol. 36. p. 1709-1731. 2002-2003. p. 1712.

165 Jim Mason e Peter Singer defendem "cinco princípios para uma alimentação ética: 1) transparência: temos o direito de saber como nosso alimento é produzido; 2) justiça: a produção de alimentos não deve impor custos sobre os outros ou custos insustentáveis sobre o meio ambiente; 3) humanidade: os alimentos devem ser produzidos sem infligir sofrimento desnecessário aos animais; 4) responsabilidade social: os trabalhadores têm direito a salários justos e condições de trabalho; e 5) Preservar a vida e a saúde justifica mais do que outros desejos: isto significa que a necessidade de uma boa nutrição é importante e pode, por vezes, triunfar sobre outros valores. Contudo, não devemos escolher alimentos que viola os princípios 1-4, quando outras opções de alimentos nutritivos estão disponíveis". MASON, Jim \& SINGER, Peter. A Ética da Alimentação: Como Nossos Hábitos Alimentares Influenciam o Meio Ambiente e o Nosso Bem-Estar. São Paulo: Campus Elsevier, 2006. p. 292-293.

166 O veganismo é visto como um princípio de justiça, não apenas como uma simples dieta ou estilo de vida, é a consubstanciação de um comprometimento ético e individual com as formas de abolição e não-violência (ahimsa) com os animais. Sobre o tema, ver: FRANCIONE, Gary L. Ahimsa and Veganism. Jain Digest. Winter, 2009. p. 09-10.

167 Sobre a transformação social e as teorias evolucionistas na sociologia ver: BOURDIEU, Pierre. O Poder Simbólico. $6^{\circ}$ ed. Rio de Janeiro: Bertrand Brasil, 2003. p. 75 e ss.

168 REGAN, Tom. The Case for Animal Rights. In SINGER, Peter (ed). Defense 
Embora se reconheça esta incongruência, não se deve ignorar o trabalho realizado e apoiado pela sociedade em prol dos animais que hoje vivem. Na política e no direito, fala-se que todos são merecedores de consideração e de medidas institucionais que aliviem seu tormento, ou seja, a abolição futura não deve significar máxima exploração dos animais de hoje ${ }^{169}$. O fim do status de coisa dos animais é o reconhecimento de um andar fatigado do próprio humanismo que se perdeu no caminho e que pede desculpa antes de fraquejar ${ }^{170}$. $\mathrm{O}$ reconhecimento de direitos não é um jogo de soma zero, mas de soma constante, e o direito brasileiro tem avançado nesse sentido, dando valor a ações que afirmem uma futura igualdade interespécies ${ }^{171}$.

Os espectros deste problema intrínseco à temática do Direito Animal devem ser percebidos, principalmente, no espaço da docência, em que é fundamental que se estimule alternativas que visem estabelecer uma solução pós-humanizada na relação humanos/não-humano, levando em consideração suas contradições, diferenças e imperfeições ${ }^{172}$.

Avançar em direção à promoção de novas oportunidades de acesso à justiça é lábaro do constitucionalismo hodierno que busca sintonia com as demandas sociais, a fim de legitimar suas decisões, especialmente, em sistemas como o brasileiro, em que os poderes instituídos encontram-se cada vez mais afastados dos anseios sociais $^{173}$.

O princípio do veganismo tenta compreender as entrelinhas do

of Animals. New York: Basil Blackwell, 1985. p. 13-26.

169 Esta preocupação com os membros da espécie mais próximos reflete o que os chineses irão chamar de conduta confucionista, isto é, um costume de obediência e lealdade às instituições postas, anestesiante de comportamentos desafiadores da ordem e do direito. Sobre o debate ambiental e animal na China, ver o trabalho de: VAN WYK, Christopher S. Reinterpreting Confucianism for environmental protection in China. Envtl. L. Rep. News \& Analysis. Vol. 33. p. 10908-10916. 2003.

170 Ver sobre uma mudança de perspectiva: SILVA, Tagore Trajano de Almeida. Direito animal e hermenêutica jurídica da mudança: a inserção da linguagem dos movimentos sociais em um novo significado jurídico. Revista Brasileira de Direito Animal. Vol. 04. p. 247-264, 2008.

171 WISE, Steven M. Thunder Without Rain: A Review/Commentary of Rain Without Thunder: The Ideology of the. Animal Rights Movement. Animal Law. Vol. 03. p. 45-60. 1997. p. 53-54.

172 Cf. SILVA, Tagore Trajano de Almeida. Teoria da Constituição: Direito Animal e Pós-Humanismo. Revista do Instituto do Direito Brasileiro da Faculdade de Direito da Universidade de Lisboa - RIDB, v. 10, p. 11683-11732, 2013.

173 Cf. GOMES, Joaquim B. Barbosa. A recepção do instituto da ação afirmativa pelo Direito. Constitucional Brasileiro. Revista de Informação Legislativa. Brasília, a.38. n. 151 jul./set. 2001. p. 131. 
desenvolvimento individual e coletivo da sociedade. Passa-se como informação institucionalizada um Brasil esplendoroso, devido ao avanço da fronteira agrícola e a pecuária, não se transmitindo os efeitos colaterais deste símbolo de progresso e sucesso nacional. Michael Fox esclarece haver vicissitudes complexas no modelo de encorajamento dos métodos de produção agrícola adotados pelo Brasil. Os brasileiros têm empregado técnicas contraproducentes de desenvolvimento de suas commodities, não compreendendo os encargos sociais, econômicos e ambientais gerados $^{174}$.

À vista disso, os países desenvolvidos têm transferido o custo de produção agrícola e animal para as demais nações, criando o que se chama de dumping ambiental e animal, ou seja, o Estado é utilizado como suporte de grandes empresas e do agronegócio. São elas que recebem recursos e proteção institucionais, corroborando com o desaparecimento de cultivos familiares, comunidades rurais, desperdício de recursos naturais e com os maus-tratos aos animais. Todos estes fatores são apontados como principais causas a agravar a pobreza e subnutrição nacional ${ }^{175}$.

O papel, portanto, do princípio do veganismo é esclarecer, informar a todos sobre este lasso caminhar, em que se perde autossuficiência agrícola e o respeito para com os demais animais, deixando um país em colapso, onde disputas sociais serão inevitáveis. A inflação rápida, produto da demanda do mercado mundial, consome a renda da população e traz de volta os fantasmas da fome, desnutrição e pobreza, causadores de instabilidade social a gerar violência e inconstância política e econômica ${ }^{176}$.

Engana-se quem compreende esta visão como um alarmismo, causador de pânico e não derivado do texto constitucional. O direito a um ambiente ecologicamente equilibrado, caput do art. 225, alude que este é dever de todos, cabendo ao estado e à coletividade a adoção de medidas mais conscientes para a interrelação local, bem como para uma agenda global ${ }^{177}$.

174 Ver, nesse sentido, FOX, Michael W. To Farm without Harm and Choosing a Humane Diet: the Bioethics of Humane Sustainable Agriculture. International: New York University Press, New York City, 1996.

175 Sobre uma conscientização ética na alimentação ver: REGAN, Tom. We are What We Eat. CAHN, Steven. (ed.). Exploring Ethics: An Introductory Anthology. Oxford: Oxford University Press, 2007.

176 FOX, Michael W. To Farm without Harm and Choosing a Humane Diet: the Bioethics of Humane Sustainable Agriculture. International: New York University Press, New York City, 1996.

177 Ver sobre este tema: LOVELOCK, James. Gaia: alerta final. Rio de Janeiro: Intrínseca, 2010. p. 99; além de LOVELOCK, James. A Vingança de Gaia. Rio de Janeiro: Intrínseca, 2006. p. 71. 


\section{Conclusão}

Ao término deste artigo, restou evidenciado o status singular dos nãohumanos na Carta Política de 1988. A nova Constituição marcou um novo momento na história brasileira, não apenas para os humanos, ao representar a síntese das diversas disputas políticas inerentes ao processo constitucional, bem como o ressurgimento da democracia após um período de ditadura; mas também, para os demais animais no momento em que se garantiu sua proteção contra toda e qualquer forma de crueldade.

Sendo assim, é possível enunciar algumas conclusões que sintetizam as ideias desenvolvidas neste trabalho:

1. A inserção do art. 225 , parágrafo $1^{\circ}$, inciso VII na Constituição de 1988 foi projeto de intenso debate e discussão em todo o país, decorrência de uma verdadeira virada kantiana, ocorrida ainda durante a Assembléia Nacional, em prol dos interesses não-humanos.

2. Pode-se dizer que o constituinte brasileiro deixou as portas abertas para a pós-humanização de sua Carta ao atualizá-la com ideais que vão além da categorização humana, reconhecendo um valor em si inerente a todos os animais não-humanos, permitindo, através de seu texto, uma interpretação que contemple a dignidade animal.

3. O constituinte, ao dirigir um dever de proteção dos animais não-humanos, veda categoricamente a submissão dos animais à crueldade, não deixando espaço para ponderações, pois, como entendido, não se pode sopesar/ponderar a crueldade, sendo necessária uma realização por completo deste mandamento.

4. Pode-se extrair do texto constitucional um imperativo categórico em defesa dos não-humanos, um sinal invisível dizendo: "Entrada proibida", a impedir que: a) os homens não são livres para desrespeitar a vida ou violar a integridade dos animais como bem entenderem; e b) o ser humano não é livre para interferir nas escolhas dos demais seres da Terra.

5. A constitucionalização do Direito Animal pós-humaniza o processo interpretativo, apresentando um novo caminho, ao entender que todos (= todos os seres vivos humanos e não-humanos da Terra) têm direito ao meio ambiente ecologicamente equilibrado, devendo defendê-lo e preservá-lo para as presentes e futuras gerações (= presentes e futuras gerações de vida no planeta).

6. Através de uma hermenêutica evolutiva proposta pelo Direito Animal, compreende-se a norma constitucional do art. 225 , parágrafo $1^{\circ}$, inciso VII como de eficácia plena e aplicabilidade imediata.

7. Há uma dupla dimensão da eficácia das normas constitucionais dirigidas aos animais não-humanos, uma a garantir direitos subjetivos protegidos pelo Estado e outra a preservar eventuais violações por parte dos particulares.

8. Surge um Constitucionalismo Pós-humanizado, a abranger o novo 
conceito de Constituição Ecológica difundida nos países europeus (Alemanha e Suíça) e ganhando forma nos países sul-americanos como a Venezuela, Bolívia e Equador.

9. O Direito Animal tem como princípios norteadores: a) a dignidade animal; b) o antiespecismo; c) a não-violência; e d) o veganismo.

\section{Referências}

ALEXY, Robert. Teoria dos Direitos Fundamentais. Trad. Virgílio Afonso da Silva. São Paulo: Malheiros, 2008.

ANTUNES, Paulo de Bessa. Direito Ambiental. 14a ed. São Paulo: Atlas, 2012.

ARENDT, Hannah. Eichmman em Jerusalém: Um relato sobre a banalidade do mal. São Paulo: Companhia das Letras; 1999.

ÁVILA, Humberto. Teoria dos princípios - da definição à aplicação dos princípios jurídicos. $2^{\mathrm{a}}$ ed. São Paulo: Malheiros, 2003.

AZEVEDO, Antônio Junqueira de. Caracterização jurídica da dignidade da pessoa humana. Revista dos Tribunais. Vol . 797. Ano. 91. p. 11-26. São Paulo: RT, Março de 2002.

BAHIA, Saulo José Casali. Human Rights from a Latin American Perspective. Forum on Public Policy. Vol. 09. p. 1-29. Summer, 2009.

BARBOSA, Rui. Comentários à Constituição Federal brasileira. São Paulo: Saraiva, 1933.

BARCELlOS, Ana Paula de. A eficácia Jurídica dos Princípios Constitucionais: O Princípio da Dignidade da Pessoa Humana. Rio de Janeiro: Renovar, 2002.

- Neoconstitucionalismo, Direitos Fundamentais e Controle das Políticas Públicas. Revista de Direito Administrativo. Vol. 240, p. 83-103, 2005.

BARILAN, Y. Michael. Speciesism as a Precondition to Justice. Politics and the Life Sciences. Vol. 23. N N$^{\text {}}$. 01. p. 22-33. Mar, 2004.

BARROSO, Luís Roberto. Gestação de fetos anencefálicos e pesquisas com célulastronco: dois temas acerca da vida e da dignidade da pessoa humana. Revista de Direito Administrativo. Rio de Janeiro. Vol. 241, p. 93-120, 2005.

. Interpretação e aplicação da Constituição: fundamentos de uma dogmática constitucional transformadora. $6^{a}$ ed. São Paulo: Saraiva, 2004.

. Neoconstitucionalismo e constitucionalização do Direito. Revista de Direito Administrativo. Rio de Janeiro, v. 240, p. 1-42, 2005.

BASTOS, Celso Ribeiro. MEYER-PFLUG, Samantha. A interpretação como fator de desenvolvimento e atualização das normas constitucionais. In SILVA, Virgílio Afonso (Coord.). Interpretação constitucional. São Paulo: Malheiros, 2005. 
BAUMAN, Zygmunt. Globalização: as consequências humanas. Rio de Janeiro: Jorge Zahar, 1999.

. Modernidade líquida. Rio de Janeiro: Jorge Zahar, 2001.

BEKOFF, Marc, and CARRON Meaney. Encyclopedia of Animal Rights and Animal Welfare. Westport, CT: Greenwood Publishing Group, Inc., 1998.

BENJAMIN, Antonio Herman. Constitucionalização do ambiente e ecologização da constituição brasileira. In: CANOTILHO, J.J. Gomes; LEITE, José Rubens Morato (org.). Direito Constitucional. Ambiental Brasileiro. São Paulo: Saraiva, 2007.

BENTHAM, Jeremy. An Introduction to the Principles of Morals and Legislation. In two volumes. London: W. Pickering, Linconln's inn fields and E. Wilson, Royal Exchange, 1823.

BEST, Steven \& NOCELLA II, Anthony J. Defining Terrorism. Animals Liberation Philosophy and Policy Journal. Vol.02. p. 56-72. Issue 1, 2004.

BOBBIO, Norberto. Teoria do ordenamento jurídico. $7^{\circ}$. ed. Trad. Maria Celeste Cordeiro Leite dos Santos. Brasília: UNB, 1996.

BOURDIEU, Pierre. O Poder Simbólico. $6^{\circ}$ ed. Rio de Janeiro: Bertrand Brasil, 2003.

BRITO, Edvaldo. Limites da revisão constitucional. Porto Alegre: Sérgio Antônio Fabris Editor, 1993.

BRUYN, Severyn T. Review of Politics of Nonviolent Action by Gene Sharp. American Journal of Sociology. Vol. 80:3. p. 795-798. Chicago: University of Chicago Press, 1974.

BRYANT, Taimie L. Mythic Non-violence. Journal of Animal Law. Vol. 02. p. 0113. 2006.

BUZANELLO, José Carlos. Direito de resistência constitucional. Brasília: América Jurídica, 2003.

CANOTILHO, José Joaquim Gomes. Democracia sustentada e Estado Constitucional Ecológico. RevCEDOUA. Vol. 02. Ano. 04. p. 09-16. 2001.

- Democracia sustentada e Estado Constitucional Ecológico. RevCEDOUA. Vol. 02. Ano. 04. p. 09-16. 2001.

Direito Constitucional e Teoria da Constituição. $7^{\circ}$ ed. Coimbra: Almedina, 2004.

CARRINGTON, Paul D. The Constitutional Law Scholarship of Thomas McIntyre Cooley. American Journal of Legal History. Vol. 41. p. 368-399. 1997.

CASSUTO, David N. The CAFO Hothouse: Climate Change, Industrial Agriculture and the Law. Policy Paper. Ann Arbor, MI: Animals and Society Institute, 2010.

CHALFUN, Mery. Paradigmas filosóficos - ambientais e o direito dos animais. Revista Brasileira de Direito Animal. Vol. 06. p. 209-246. Jan/Jun. Salvador: 
Evolução, 2010.

CHRISTIE, George C. The Model of Principles. Duke Law Journal. Vol. 17. p. 649669. 1968.

COOLEY, Thomas M. A Treatise on the Constitutional Limitations Which Rest upon the Legislative Power of the States of the American Union. $5^{\circ}$ ed. Boston: Little, Brown \& Co., 1883.

CUSTÓDIO, Helita Barreira. Crueldade contra animais e a proteção destes como relevante questão jurídico-ambiental e Constitucional. Revista de Direito Ambiental. Vol. 10. abril/junho. São Paulo: Revista dos Tribunais, 1997.

DAMATTA, Roberto. Carnavais, Malandros e Herois. Rio de Janeiro: Rocco, 1997. DAWKINS, Richard. Gaps in the Mind. In CAVALIERI, Paola \& SINGER, Peter (Ed). The Great Ape Project.: Equality Beyond Humanity, New York: St. Martin's Press, 1993.

DIAS, Edna Cardozo. A Defesa dos animais e as conquistas legislativas do movimento de proteção animal no Brasil. Revista Brasileira de Direito Animal/Brazilian Animal Rights Review. Ano 02. Vol. 02. jan/jun. Salvador: Evolução, 2007. p. 123-142.

A Defesa dos animais e as conquistas legislativas do movimento de proteção animal no Brasil. Revista Brasileira de Direito Animal. Vol. 02. n. 1. jan/ jun. p. 123-142. Salvador: Evolução, 2007. p. 134

DIMOULIS, Dimitri; MARTINS, Leonardo. Teoria geral dos direitos fundamentais. São Paulo: Revista dos. Tribunais, 2008.

DINIZ, Maria Helena. Normas constitucionais e seus efeitos. Saraiva: São Paulo, 1989.

DWORKIN, Ronald. Levando os direitos a sério. Trad. Nelson Boeira. 2 ed. São Paulo: Martins Fontes, 2007. 1977. . Taking Rights Seriously. Cambridge, MA: Harvard University Press, 14- 46. 1967.

. The Model of Rules. University of Chicago Law Review. Vol. 34. p.

FELDMANN, Fábio. Os tribunais e o direito à vida do pato mergulhão. In: Brasil Econômico. Disponível em: http://brasileconomico.ig.com.br/noticias/os-tribunaise-o-direito-a-vida-do-pato-mergulhao_134442.html. Acessado em: 01 de Agosto de 2013.

FELIPE, Sônia T. Dos Direitos morais aos Direitos Constitucionais: Para além do especismo elitista e eletivo. Revista Brasileira de Direito Animal/Brazilian Animal Rights Review. Vol. 02. Ano. 1. Jan/Jun. p. 143-159. Salvador: Evolução, 2007. . Fundamentação ética dos direitos animais. O legado de Humphry Primatt. Revista Brasileira de Direito Animal. Vol. 01. Ano. 1. Salvador: Instituto 
Abolicionista Animal, 2006.

FENSTERSEIFER, Tiago. Direitos Fundamentais e Proteção do Ambiente: a dimensão ecológica da dignidade humana no marco jurídico-constitucional do Estado Socioambiental de Direito. Porto Alegre: Livraria do Advogado, 2008.

FOLEY, Conor. Combate à tortura: Manual para magistrados e membros do Ministério Público. Reino Unido: Human Rights Centre, University of Essex, 2003. FOX, Michael W. To Farm without Harm and Choosing a Humane Diet: the Bioethics of Humane Sustainable Agriculture. International: New York University Press, New York City, 1996.

FRANCIONE, Gary L. Ahimsa and Veganism. Jain Digest. Winter, 2009.

. Reflections on animals, property, and the law and rain without thunder. Law and Contemporary Problems. Vol. 70. p. 09-57. Winter 2007.

. Taking Sentience Seriously. Journal of Animal Law and Ethics. Vol. 01. p. 01-18. May, 2006.

FUKUYAMA, Francis. Nosso Futuro Pós-Humano: Consequências da Revolução da Biotecnologia. Trad. de Maria Luiza X. de A. Borges. Rio de Janeiro: Rocco, 2003.

GARVER, Eugene. Review of Politics of Nonviolent Action by Gene Sharp. Ethics. Vol: 84:3. p. 266-273. Chicago: University of Chicago Press, 1974.

GOMES, Joaquim B. Barbosa. A recepção do instituto da ação afirmativa pelo Direito. Constitucional Brasileiro. Revista de Informação Legislativa. Brasília, a.38. n. 151 jul./set. 2001.

GORDILHO, Heron José de Santana \& SILVA, Tagore Trajano de Almeida. Animais em Juízo: direito, personalidade jurídica e capacidade processual. Revista de Direito Ambiental. Vol. 65. p. 333-363, 2012.

\& SILVA, Tagore Trajano de Almeida. Habeas Corpus para os grandes primatas. Revista do Instituto do Direito Brasileiro da Faculdade de Direito da Universidade de Lisboa-RIDB. Vol. 04. p. 2077-2114, 2012.

$85-109,2004$ Abolicionismo Animal. Revista de Direito Ambiental. Vol. 36. p.

Direito Ambiental pós-moderno. Curitiba: Juruá, 2009.

SANTANA, Luciano Rocha; SILVA, Tagore Trajano de A.. [et. al]. Habeas Corpus impetrado em favor da chimpanzé Suíça na $9^{a}$ Vara Criminal de Salvador (BA). Revista Brasileira de Direito Animal. Vol. 01. Ano. 01. Jan/Dez. Salvador: Instituto de Abolicionismo Animal, 2006.

GRAU, Eros Roberto. Ensaio e discurso sobre interpretação/aplicação do direito. São Paulo: Malheiros, 2002.

HABERLE, Peter. A dignidade humana como fundamento da comunidade estatal. 
In: SARLET, Ingo Wolfgang (Org.). Dimensões da dignidade: ensaios de filosofia do direito e direito constitucional. 2. ed. Porto Alegre: Editora Livraria do Advogado, 2009. p. 89-152.

HARRISON, Ruth. Animal Machine. Londres: Vicent Stuart, 1964.

HESSE, Konrad. A Força Normativa da Constituição. Porto Alegre: Sergio Antônio Fabris, 1991.

HUGHES, Graham. Rules, Policy and Decision Making, Yale Law Journal. Vol.. 77. p. 411-439. n. 03. January, 1968.

JONAS, Hans. El principio de responsabilidad: ensayo de una ética para la civilización tecnológica. Barcelona: Herder, 1995. Ver também em: SIQUEIRA, José Eduardo de. El principio de responsabilidad de Hans Jonas. In Acta bioeth., 2001, vol.7, no.2, p.277-285. ISSN 1726-569X.

KANT, Immanuel. Fundamentação da metafísica dos costumes. Trad. A. Pinto de Carvalho. São Paulo: Editora Nacional, 1964.

KEAN, Hilda. Animal rights: political and social change in Britain since 1800, Reaktion Books, 1998.

KELCH, Thomas G. Globalization and Animal Law: Comparative Law, International Law and International Trade. Great Britain: Kluwer Law International, 2011.

KELSEN, Hans, Teoria pura do direito. Trad. João Baptista Machado. 6 ed. São Paulo: Martins Fontes, 1998.

KRELL, Andreas J. Constituição e direitos dos animais. Palestra proferida no $3^{\circ}$ Congresso Mundial de Bioética e Direitos dos Animais. Realizada em 25 de Agosto de 2012. Recife: Universidade Federal de Pernambuco, 2012.

. Direitos Sociais e Controle Judicial no Brasil e na Alemanha - os

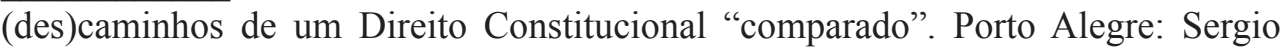
Antonio Fabris Editor, 2002.

LARENZ, Karl. Metodologia da ciência do direito. Trad. José Lamego. Lisboa: Calouste Gulbenkian, 1997.

LASSALLE, Ferdinand. A Essência da Constituição. $6^{\mathrm{a}}$ ed. Rio de Janeiro, Lumen Juris, 2001.

. O que é uma Constituição. Belo Horizonte: Ed. Líder, 2002.

LEITE, José Rubens Morato, AYALA, Patrick de Araújo. Direito ambiental na sociedade de risco. $2^{\mathrm{a}}$. ed. Rio de Janeiro: Forense Universitária, 2004.

LEUBSDORF, John. Gandhi's legal ethics. Rutgers Law Review. Vol. 51. p. 923939. 1998-1999.

LIEBMAN, Matthew. I Fought the Law: a review of terrorists or freedom fighters? Reflections on the Liberation of Animals, edited by Steven Best \& Anthony J. Nocella II. Journal of Animal Law. Vol. 01. p. 151-169. 2005. 
LIMA, Martônio Mont'Alverne Barreto. Política versus Direito: Real Desafio da Jurisdição Constitucional?. In: Lorena Freitas; Enoque Feitosa. (Org.). Marxismo, Realismo e Direitos Humanos. João Pessoa - PB: Editora da Universidade Federal da Paraíba, 2012, v. 1, p. 52-66.

LOURENCO, Daniel Braga. \& OLIVEIRA, Fábio Corrêa Souza de. Sustentabilidade, Economia Verde, Direito dos Animais e Ecologia Profunda: algumas considerações. Revista Brasileira de Direito Animal. Vol. 10. Ano. 07. p. 191-233, 2012.

. Direito de imagem para animais? Publicado em: 22 de março de 2010 às 17:56. Disponível em: http://www.anda.jor.br/22/03/2010/direito-deimagem-para-animais. Acessado em: 10 de julho de 2013.

. Direito dos Animais: fundamentação e novas perspectivas. Porto Alegre: Sergio Antônio Fabris, 2008. p. 491.

LOVELOCK, James. A Vingança de Gaia. Rio de Janeiro: Intrínseca, 2006.

Gaia: alerta final. Rio de Janeiro: Intrínseca, 2010.

MACHADO, Paulo Affonso Leme, Direito Ambiental Brasileiro. 13 ${ }^{\mathrm{a}}$ ed. São Paulo: Malheiros, 2005.

MACKINNON, Catharine A. Of Mice and Men: A Feminist Fragment on Animal Rights. In SUNSTEIN, Cass \& NUSSBAUM, Martha (eds). Animal Rights: current debates and new directions. p. 263-276. Oxford University Press, 2004.

MARIANO, Cynara Monteiro \& LIMA, Martônio Mont'Alverne Barreto. Os Paradigmas Tradicionais de Justiça Constitucional e a Terceira Via do Sistema Francês. Novos Estudos Jurídicos (Online). Vol. 17. n. 02. p. 173-184. Maio/Agosto, 2012.

MARINHO, Josaphat. Uma perspectiva da nova Constituição brasileira. Revista Forense. Vol. 84. n. 304, p. 101 -105, out/dez. Rio de Janeiro: Forense, 1988.

MASON, Jim \& SINGER, Peter. A Ética da Alimentação: Como Nossos Hábitos Alimentares Influenciam o Meio Ambiente e o Nosso Bem-Estar. São Paulo: Campus Elsevier, 2006.

MEDEIROS, Fernanda Luiza Fontoura de. Direito dos animais. Porto Alegre: Livraria do Advogado, 2013.

MELlO, Celso Antônio Bandeira de. Conteúdo Jurídico do Princípio da Igualdade. $3^{\mathrm{a}}$ ed. São Paulo: Malheiros, 2004.

MENDES, Gilmar Ferreira. COELHO, Inocêncio Mártires. BRANCO, Paulo Gustavo Gonet. Curso de direito constitucional. 2.ed. São Paulo: Saraiva, 2008.

MILL, John Stuart. Utilitarianism. 2a . ed. Longmans, Green, Reader \& Dyer, 1863.

MIRANDA, Jorge. Manual de direito constitucional. Tomo II: Constituição. $6^{\mathrm{a}}$ ed. Coimbra: Coimbra, 2007.

MOREIRA NETO, Diogo de Figueiredo. Transição constitucional (pela estabilidade 
democrática). Revista Forense. vol. 304. p. 63-68. Rio de Janeiro: Forense, 1988. NACONECY, Carlos M. As (des)analogias entre racismo e especismo. Revista Brasileira de Direito Animal. Vol. 06. Ano. 05. p. 173-208. Jan/Jun. Salvador: Evolução, 2010.

NUSSBAUM, Martha C. Para além de compaixão e humanidade: justiça para animais não-humanos. In MOLINARO, Carlos Alberto; SARLET, Ingo Wolfgang. [et. al] (orgs.) A dignidade da vida e os direitos fundamentais para além dos humanos: uma discussão necessária. Belo Horizonte: Fórum, 2008. p. 85-126.

OLIVEIRA, Fábio Corrêa Souza de. Especismo religioso. Revista Brasileira de Direito Animal. Vol. 08. Ano 06. p. 161- 220. Jan/Jun. Salvador: Evolução, 2011.

. Por uma Teoria dos Princípios. O Princípio Constitucional da Razoabilidade. Rio de Janeiro: Lumen Juris, 2003.

PASTAN, Amy. Gandhi: A photographic story of a life. DK Publishing, 2006; e PASTAN, Amy. Martin Luther King, Jr.: A photographic story of a life. DK Publishing, 2004.

PILATTI, Adriano. A Constituinte de 1987-1988: progressistas, conservadores, ordem econômica e regras do jogo. Rio de Janeiro: Lúmen Júris, 2008.

PORCHEDDU, Alba. Zygmunt Bauman: entrevista sobre a educação. Desafios pedagógicos e modernidade líquida. Cad. Pesquisa., São Paulo, v. 39, n. 137, Aug. 2009. Available from <http://www.scielo.br/scielo.php?script=sci arttext\&pid=S0100-15742009000200016\&lng=en\&nrm=iso $>$. Access on 03 June 2012. http://dx.doi.org/10.1590/S0100-15742009000200016.

RABENHORST, Eduardo Ramalho. Dignidade Humana e Moralidade Democrática. Brasília: Brasília Jurídica, 2001.

RAWLS, John. Uma teoria de justiça. Trad. Almiro Pisetta e Lenita Maria Rímoli Esteves. $2^{\mathrm{a}}$ ed. São Paulo: Martins Fontes, 2002.

RAZ, Joseph. Legal principles and the limits of law. Yale Law Journal. Vol. 81. p. 823-854. 1972. p. 825 e ss.

REGAN, Tom. How to Justify Violence. In BEST, Steven \& NOCELLA II, Anthony J. Terrorists or Freedom Fighters? Reflections on the Liberation of animals. 2004. . Jaulas Vazias. Porto Alegre: Lugano, 2006.

Animals. New York: Basil Blackwell, 1985.

The Case for Animal Rights. In SINGER, Peter (ed). Defense of . The case of animal rights. $2^{\mathrm{a}}$. ed. Califórnia: University of California

Press, 2004.

We are What We Eat. CAHN, Steven. (ed.). Exploring Ethics: An Introductory Anthology. Oxford: Oxford University Press, 2007.

ROCHA, Cármen Lúcia Antunes. Ação Afirmativa: o conteúdo democrático do 
princípio da igualdade jurídica. Revista de Informação Legislativa. Vol. 33. nº 131. p. 283-295, jul./set. de 1996.

RYDER, Richard. Speciesism and 'painism'. The Animal's Agenda. 1997.

SANTANA, Luciano Rocha \& SANTOS, Clarissa Pereira Gunça dos. O crime de maus-tratos aos animais: uma abordagem sobre a interpretação e a prova de materialidade e autoria (artigo 32). In MARCHESAN, Ana Maria Moreira \& STEIGLEDER, Annelise Monteiro. (org.). Crimes Ambientais Comentários à Lei 9.605/98. Porto Alegre: Livraria do Advogado, 2013.

. Ministério Público e Éticas da Natureza. In OLIVEIRA, Thiago Pires; MINAHIM, Maria Auxiliadora; FREITAS, Tiago Batista. (Org.). Meio ambiente, direito e biotecnologia: estudos em homenagem ao Prof. Dr. Paulo Affonso Leme Machado. Curitiba: Juruá, 2010.

SANTOS, Boaventura de Sousa. Por uma concepção multicultural de direitos humanos. Revista Crítica de Ciências Socias. nº 48. Junho, 1997.

SARLET, Ingo Wolfgang, FENSTERSEIFER, Tiago. Algumas notas sobre a dimensão ecológica da dignidade da pessoa humana e sobre a dignidade da vida em geral. Revista Brasileira de Direito Animal/Brazilian Animal Rights Review. Salvador. Vol. 03. ano 02. p. 69-94. jul/dez. 2007.

., FENSTERSEIFER, Tiago. Direito Constitucional Ambiental: Estudos sobre a Constituição, os Direitos Fundamentais e a Proteção do Ambiente. São Paulo; Editora Revista dos Tribunais, 2011. p. 166.

do advogado, 2007.

A eficácia dos Direitos Fundamentais. ${ }^{\mathrm{a}}$. Ed. Porto Alegre: Livraria

- Dignidade da Pessoa Humana e Direitos Fundamentais na Constituição Federal de 1988. 5. ed. Porto Alegre: Livraria do Advogado, 2007.

SARMENTO, Daniel. Direitos fundamentais e relações privadas. $2^{\mathrm{a}}$. ed. Rio de Janeiro: Lumen Juris, 2006.

.Livres e Iguais: Estudos de Direito Constitucional. Rio de Janeiro:

Lumen Juris, 2006. p. 145.

SARMENTO, Daniel. Ubiquidade constitucional: os dois lados da moeda. Livres e iguais: estudos de direito constitucional. Rio de Janeiro: Lumen Juris, 2010.

SHARP, Gene. The Politics of Nonviolent Action. Boston: Porter Sargent, 1973.

SILVA NETO, Manoel Jorge e. Curso de Direito Constitucional. 6 ${ }^{\text {a }}$.ed. Rio de Janeiro: Lúmen Júris, 2010.

SILVA, José Afonso da. O constitucionalismo brasileiro - evolução institucional. São Paulo: Malheiros, 2011.

- Aplicabilidade das Normas Constitucionais. $7^{\mathrm{a}}$ ed. São Paulo: Malheiros, 2008. STEINMETZ, Wilson. A vinculação dos particulares a direitos 
fundamentais. São Paulo: Malheiros, 2004.

SILVA, Tagore Trajano de Almeida. A Lei Arouca: ainda continuamos a realizar pesquisas com animais. Pensata Animal. Vol. 17, p. 01-06, 2008.

. Afirmação histórica dos direitos dos animais à luz dos trabalhos de Peter Singer e Tom Regan. In: Anais do $16^{\circ}$ Congresso Internacional de Direito Ambiental, o $6^{\circ}$ Congresso de Direito Ambiental dos Países de Língua Portuguesa e Espanhola e o $6^{\circ}$ Congresso de Estudantes de Direito Ambiental - PNMA: 30 anos da Política Nacional de Meio Ambiente. São Paulo: Imprensa Oficial do Estado de São Paulo, 2011. v. 01. . Animais em juizo. Salvador: Evolução, 2012.

. Brazilian Animal Law Overview: Balancing Human and NonHuman Interests. Journal of Animal Law. Vol. 06. p. 81-104. 2010.

. Direito Animal e ensino jurídico: formação e autonomia de um saber pós-humanista. 1. ed. Salvador: Evolução, 2014.

. Direito animal e hermenêutica jurídica da mudança: a inserção da linguagem dos movimentos sociais em um novo significado jurídico. Revista Brasileira de Direito Animal. Vol. 04. p. 247-264, 2008.

Vol. 62. p. 141-168, 2011.

Introdução aos direitos dos animais. Revista de Direito Ambiental.

. LANGERHORST, Victor. \& BRAGA, Sérgio. Fundamentos do Direito Animal Constitucional. Revista Brasileira de Direito Animal. Ano 7. Vol. 10. jan/jun. p. 233-274. 2012.

. Teoria da Constituição: Direito Animal e Pós-Humanismo. Revista do Instituto do Direito Brasileiro da Faculdade de Direito da Universidade de Lisboa - RIDB, v. 10, p. 11683-11732, 2013.

- GORDILHO, Heron José de Santana. Eficácia dos direitos fundamentais e justiça distributiva: o interesse público como problema jurídico nos tratamentos de saúde. Jurispoiesis (Rio de Janeiro). Vol. 14. p. 149-176, 2011.

SILVA, Virgílio Afonso da. A constitucionalização do direito: os direitos fundamentais nas relações entre particulares. São Paulo: Malheiros, 2005,

SINGER, Peter. All animals are equal. In: Defense of animals: the second wave. Oxford: Blackwell, 2006.

Animal liberation. The New York Review of Books. Vol. 20. N 05. Published in 05 de Abril de 1973.

Martins Fontes, 2006.

Ética prática. Trad. Jefferson Luís Camargo. $3^{\mathrm{a}}$ ed. São Paulo:

SIQUEIRA, José Eduardo de. El principio de responsabilidad de Hans Jonas. Acta bioeth., 2001, vol.7, no.2, p.277-285. ISSN 1726-569X.

SOARES, Ricardo Maurício Freire. O princípio constitucional da dignidade da 
pessoa humana: em busca do direito justo. São Paulo: Saraiva, 2010.

SOIFER, Sarah. Vegan Discrimination: an Emerging and Difficult Dilemma. Loyola of Los Angeles Law Review. Vol. 36. p. 1709-1731. 2002-2003.

STALLWOOD, Kim. A Personal Overview of Direct Action in the United Kingdom and the United States, In BEST, Steven \& NOCELLA II, Anthony J. Terrorists or Freedom Fighters? Reflections on the Liberation of animals. p. 81-93. 2004.

STEINBERG, Rudolf, Judicial Review of Environmentally-Related Administrative Decision-Making, 11 Tel Aviv U. Stud. L. 61, 64 (1992) e Enforcing Environmental Laws: The Role of Public Law n Environmental Protection - a European Perspective 14 Tel Aviv U. Stud. L. 431998.

TAVARES, Ana Lúcia de Lyra. A Constituição Brasileira de 1988: subsídios para os comparatistas. Revista de Informação Legislativa. Brasília. Ano 28. nº. 109. jan/mar. p. 71-108. 1991.

VAN WYK, Christopher S. Reinterpreting Confucianism for environmental protection in China. Envtl. L. Rep. News \& Analysis. Vol. 33. p. 10908-10916. 2003. VENÂNCIO FILHO, Alberto. Sobral Pinto, o Advogado. Revista da EMERJ. Vol. 12, no 45, p. 195-203, 2009.

WALDAU, Paul. The Specter of Speciesism: Buddhist and Christian Views of Animals. Oxford and New York: Oxford University Press, 2002.

WALDAU, Paul. Will the heavens fall? De-radicalizing the precedent-breaking decision. Animal Law. Vol. 07. p. 75-117. 2001.

WINCKLER, Marly. Fundamentos do Vegetarianismo. Rio de Janeiro: Expressão e Cultura, 2004.

WISE, Steven M. Thunder Without Rain: A Review/Commentary of Rain Without Thunder: The Ideology of the. Animal Rights Movement. Animal Law. Vol. 03. p. 45-60. 1997. 